\title{
1. EPISODIC DEPOSITION OF PLIOCENE-PLEISTOCENE PUMICE FROM THE IZU-BONIN ARC, LEG $126^{1}$
}

\author{
Akira Nishimura, ${ }^{2}$ Kelvin S. Rodolfo, ${ }^{3}$ Akiko Koizumi, ${ }^{4}$ James Gill, ${ }^{5}$ and Kantaro Fujioka ${ }^{6}$
}

\begin{abstract}
Thick pumice deposits were found in the cored sequences of forearc, arc, and backarc sites of Leg 126 in the Izu-Bonin Arc. These deposits, composed of fragmental rhyolite pumice with the chemical composition of low-alkali tholeiites, are products of arc volcanism. Pumice deposits constitute more than half of the thickness of the sediment fill of the Sumisu Rift, a backarc rift of the Izu-Bonin Arc. They comprise five thick pumiceous beds separated by thin hemipelagic units; as such, they record four major episodes or pulses of explosive, rhyolitic volcanism during the last $0.15 \mathrm{Ma}$, separated by quiescent intervals that each lasted about $30-60$ k.y. The thick pumiceous beds were deposited in the rift mainly by sediment gravity flows during and immediately after the eruption of arc volcanos, which were probably submarine. Initiation of rifting was also preceded in the Pliocene by submarine rhyolitic volcanism, as seen in samples from the top of the eastern rift flank. Thick pumice beds correlative with those in the backarc also occur in the forearc basin to the east.
\end{abstract}

\section{INTRODUCTION}

Volcanism along the Izu-Bonin Arc is attested to by recorded eruptions on the volcanic islands, and by submarine volcanic rocks that have been collected by research vessels. One of the primary objectives of Ocean Drilling Program (ODP) Leg 126 was to establish the timing of the initiation and development of the Sumisu Rift. Before Leg 126, no scientific drilling had been conducted along the Izu-Bonin Arc, although several holes had been drilled in the Mariana Arc to the south by Deep Sea Drilling Project (DSDP) Legs 6, 31, 59, and 60 . Leg 125 drilled Site 785 in the Izu-Bonin forearc basin, but encountered a thick pumice layer from which recovery was poor. Leg 126 drilled two sites $2.4 \mathrm{~km}$ apart in the Sumisu Rift (Sites 790 and 791), one site (788) on the eastern rift flank top, and three sites (787, 792, and 793) in the forearc basin (Fig. 1). The cores from the rift basin and rift flank consist primarily of thick, Pliocene-Pleistocene pumiceous deposits. These new cores have provided much needed evidence for arc volcanism south of Tokyo, because Japanese records of eruptions along the Izu-Bonin Arc are scarce compared with data for other regions of Japan.

Existing models of backarc-basin sedimentation in their tectonic context (Karig and Moore, 1975; Carey and Sigurdsson, 1984; Klein, 1985 ) are based on very sparse sedimentologic data, largely because the coarse and friable volcanogenic sediments are difficult to drill and core, and so complete or even well-recovered sequences like those obtained at Sites 790 and 791 are very rarely obtained. In this paper we describe the sedimentology and petrology of the pumice deposits, determine their origin and mode of deposition, and explicate their evidence for the geologic history of the Izu-Bonin Arc. We pay particular attention to the great thickness of pumiceous rift-basin fill

\footnotetext{
${ }^{1}$ Taylor, B., Fujioka, K., et al., 1992. Proc. ODP, Sci. Results, 126: College Station, TX (Ocean Drilling Program).

${ }^{2}$ Marine Geology Department, Geological Survey of Japan, 1-1-3 Higashi, Tsukuba, Ibaraki 305, Japan.

${ }^{3}$ Department of Geological Sciences, M/C 186, University of Illinois at Chicago, P.O. Box 4348, Chicago, IL 60680, U.S.A.

${ }^{4}$ Institute of Geosciences, Shizuoka University, 836 Oya, Shizuoka 422, Japan.

${ }^{5}$ Department of Earth Sciences, University of California at Santa Cruz, Santa Cruz, CA 96064, U.S.A.

${ }^{6}$ Ocean Research Institute, University of Tokyo, 1-15-1 Minamidai, Nakano, Tokyo 164, Japan (present address: Japan Marine Science and Technology Center, 2-14 Natsushima, Yokosuka, Kanagowa 238, Japan).
}

at Sites 790 and 791, and describe the deposits of the rift flank and the forearc.

\section{GEOLOGIC SETTING}

The Izu-Bonin Arc (Fig. 1), situated between the northwestern Pacific and the Philippine Sea, was formed since the Eocene by intense bonititic, calc-alkaline, and tholeiitic volcanism (Honza and Tamaki, 1985). The north-trending volcanic front, approximately 200 $\mathrm{km}$ west of the axis of the Izu-Bonin Trench, comprises a line of active subaerial and submarine volcanos with discontinuous backarc rifts, including the Sumisu Rift immediately behind the volcanic front between Sumisu Jima and Tori Shima islands (Honza and Tamaki, 1985; Brown and Taylor, 1988; Murakami, 1988; Taylor et al., 1990). This rift (Fig. 2) consists of north and south basins, separated by small volcanic ridges, and is buried in sediments so thick that the two-way traveltime exceeds $1.2 \mathrm{~s}$ on seismic reflection records (Murakami, 1988). The volcanic history of the arc is not well understood, and most of the information comes from the geology of the islands and from cores taken in the Philippine Sea. In the northern part of the arc, in addition to the island and submarine volcanos, six submarine calderas have recently been discovered (Fig. 1). These are, from north to south, the Higashi-Aoga Shima, Kita-Beyonesu, Myojin Sho, Sumisu, MinamiSumisu, and Tori Shima calderas (Murakami and Ishihara, 1985; Takada and Yuasa, 1990; Taylor et al., 1990). During their generation, all these calderas are thought to have produced large quantities of pumice. The famous Myojin Sho eruption in 1952 (Niino et al., 1953) is the most recent pumice-producing episode in the arc.

\section{METHODS}

Original shipboard visual core descriptions (Taylor, Fujioka, et al., 1990) provide the stratigraphic, temporal, and areal distributions of pumice deposits in the core sequences of Leg 126. We also report additional analyses of pumice deposits sampled by Leg 125 at Site 785 in the forearc basin east of the Sumisu Rift. The ages of the deposits were determined using biostratigraphic and magnetostratigraphic data. Grain-size distributions were determined by using standard sieving methods for sand-size grains, and a Shimadzu Co Ltd. SALD1100 Laser Beam Particle Size Analyzer for silt- and clay-size grains. The grain types of sand-size grains of the pumice deposits were determined with a binocular microscope. The vesicularity and mineral composition of the pumice were estimated using the color-index method. 


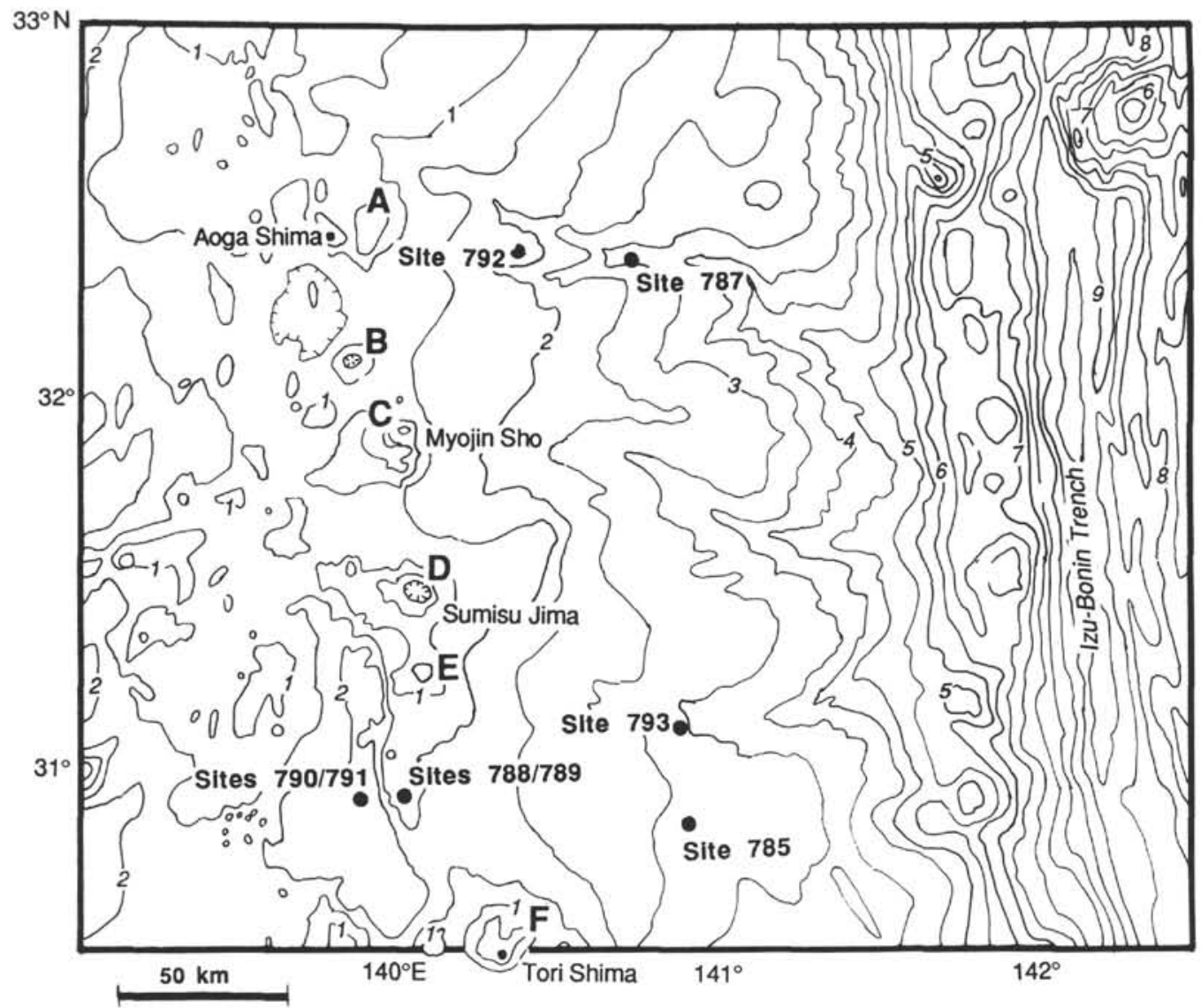

Figure 1. Bathymetric chart of study area and its volcanos, showing Leg 126 sites. Bathymetry in kilometers, contour interval 0.5 km, from Taylor, Fujioka, et al. (1990, p. 8). Calderas are as follows: A = Higashi-Aoga Shima, B = Kita-Beyonesu, C= Myojin Sho, D = Sumisu Jima, E = Minami-Sumisu, and F = Tori Shima.

Two to six pumice clasts were analyzed from each sample for major-element chemistry. A fused glass bead was made from each clast by heating a powdered split on an iridium plate at about $1200^{\circ} \mathrm{C}$ for $20 \mathrm{~s}$. Polished sections of the glass beads were analyzed with a JEOL Model JCXA-733 electron probe microanalyzer, using 10-s counting time, with a $10-\mu \mathrm{m}$ diameter defocused beam at $15 \mathrm{kV}$, and $1.2 \times 10^{-7} \AA$. Measurements were taken at $5-9$ points on each sample and reported as an average that is within $1.5 \mathrm{wt} \%$ for each oxide studied. The results of the individual analyses are shown in the Appendix.

\section{PUMICE DEPOSITS}

In this section, we describe and discuss pumice deposits that occur in layers, each thicker than several meters, in the Pliocene-Pleistocene sequences of Leg 126 and Site 785 of Leg 125 (Fig. 1). The data for the following descriptions can be found in Taylor, Fujioka, et al. (1990).

\section{Backarc Pumice Deposits}

The total sedimentary accumulations at Sites 790 and 791 in the Sumisu Rift are roughly equivalent in age: $1.1 \mathrm{Ma}$ at Site 790 and about 1.0 Ma at Site 791. However, the thickness of the deposits is very different: $271 \mathrm{~m}$ at Site 790 and $834 \mathrm{~m}$, or over three times thicker, at Site 791. This difference in thickness is attributable to the sedimentologic response to the tectonic movements related to halfgraben formation. The sedimentary successions are similar at the two sites and are divided into the same two units (Fig. 3). Unit I at both sites is the principal concern of this report. Unit II, deposited between
1.1 and $0.20 \mathrm{Ma}$, consists of burrowed nannofossil-rich clay, silty clay, and clayey silt with thin intercalations of volcanic ash. It is $106 \mathrm{~m}$ thick and unconsolidated at Site 790; at Site 791 it is 406 m thick and has been lithified by the greater overburden pressures.

Unit I, overlying Unit II at 165 mbsf at Site 790 (Fig. 3) and 428 mbsf at Site 791 , was deposited after $0.20 \mathrm{Ma}$ and consists primarily of five beds that range in thickness from 8 to $37 \mathrm{~m}$ at Site 790 (Fig. 4) and from 29 to $118 \mathrm{~m}$ at Site 791 (Fig. 5). At Site 790, where recovery from Unit I was excellent, each of these beds is a sequence that fines upward from coarse pumiceous tephra and sand-size vitric ash to siltand clay-size ash. The lower portions of some of the beds contain parallel-laminated sandy portions and darker-colored partings of scoriaceous sand and basaltic rock fragments. We have numbered the thick pumiceous beds I to $\mathrm{V}$ in order of increasing depth below the seafloor. They are separated from each other by thinner successions of clay-nannofossil hemipelagites with minor, thin ash intercalations. At Site 790, these hemipelagite successions are 3-15.5 m thick.

Recovery was not as good at Site 791, and so the thicknesses of the pumiceous and hemipelagic intervals are not as well known, especially at the bottom of the unit. Consequently, most of the following descriptive detail for each of the thick pumiceous beds comes from Site 790. In general, the successions at Site 791 differ from those at Site 790 in the following ways: (1) the pumiceous beds, beside being about three to four times thicker, are more complex, each comprising several coarse and fine successions; (2) some of the coarser intervals contain muddy intraclasts, and (3) the hemipelagic intervals between the thick pumiceous beds also tend to be thinner. These characteristics are best interpreted as resulting from episodes 


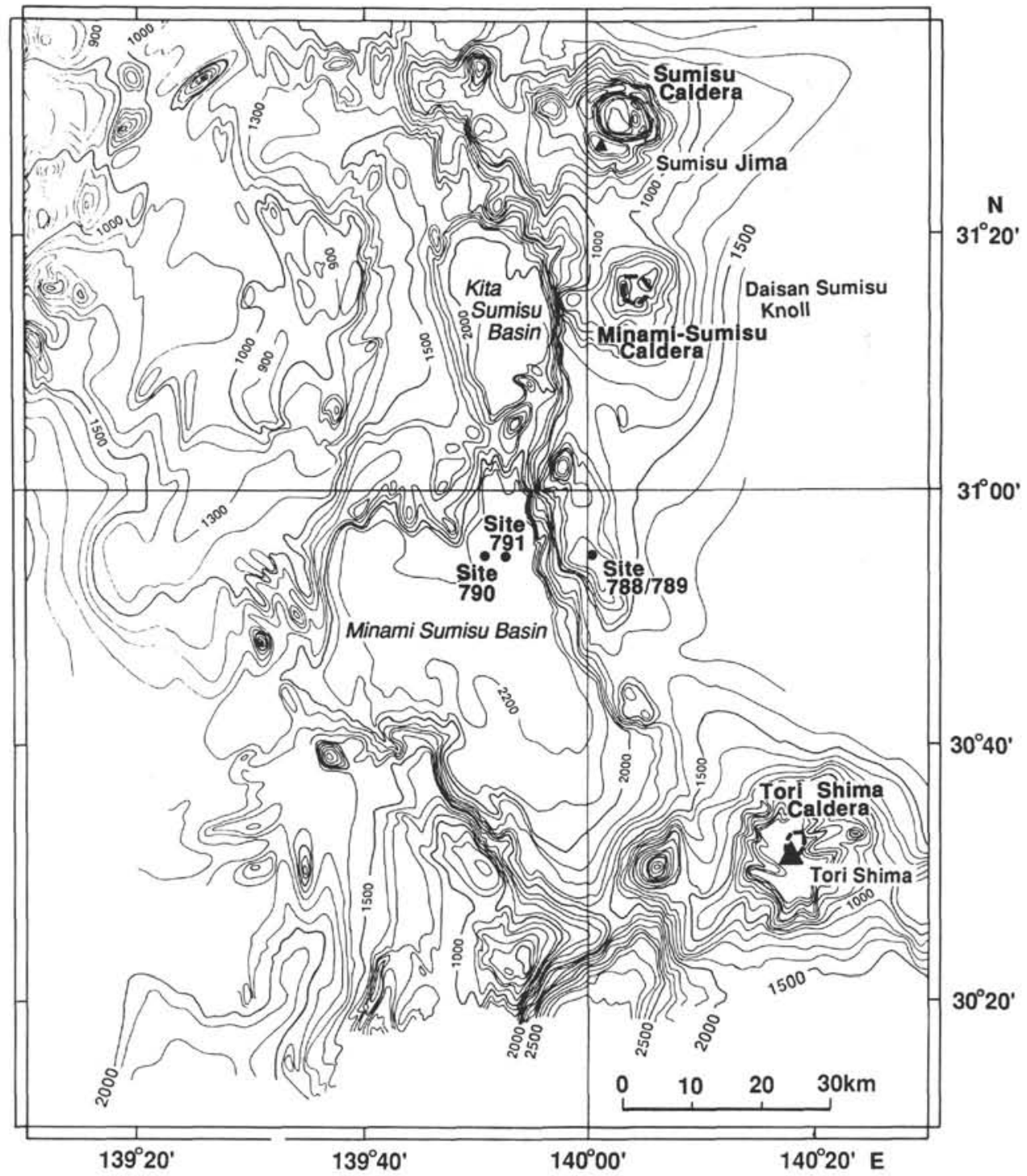

Figure 2. Bathymetry of the Sumisu Rift (from Murakami, 1988), illustrating Izu-Bonin backarc sites drilled on Leg 126. Contour interval is $100 \mathrm{~m}$.

of sediment remobilization at the eastern flank uplift and redeposition at the rift-basin depocenter. Site 790, being more distally located, was much less affected by such events.

\section{Thick Pumiceous Bed I}

At Site 790 (Fig. 4), this bed is about $8 \mathrm{~m}$ thick and has a basal portion of grayish black (N2), sand-size pumice, although its lower part is composed primarily of light olive gray (5Y6/2), sand-size pumiceous ash. Its upper part consists of light olive gray (5Y6/1), silt-size ash. At Site 791 (Fig. 5), the layer is about $29 \mathrm{~m}$ thick, and its lower part contains admixed, pebble-size pumiceous tephra. The top of the bed lies just below the seafloor, being overlain by a hemipelagic layer typically about $10 \mathrm{~cm}$ thick (Plate 1, Fig. 1), as seen in the tops of gravity cores from the Minami Sumisu Basin (Nishimura and Murakami, 1988). The entire bed probably corresponds to the uppermost, transparent, $10-20 \mathrm{~m}$ thick stratum in $3.5-\mathrm{kHz}$ sub-bottom profiling records (Brown and Taylor, 1988). It is separated from Thick Pumiceous Bed II by a hemipelagic interval that is $10.6 \mathrm{~m}$ thick at Site 790 and $11 \mathrm{~m}$ thick at Site 791.

\section{Thick Pumiceous Bed II}

This bed is the thickest of the three uppermost pumiceous beds, for which we have the data to reconstruct complete successions. It is 37 and $118 \mathrm{~m}$ thick at Sites 790 and 791, respectively. At Site 790 (Fig. 4), its basal $20 \mathrm{~m}$ consists of light olive gray (5Y6/1), pebble-size pumiceous tephra (Plate 1, Fig. 2), succeeded by $12 \mathrm{~m}$ of gray (5Y5/1) to olive gray (5Y4/1), sand-size pumiceous ash, and an uppermost 5-m thickness of olive gray (5Y5/1), silt-size ash. At Site 791 (Fig. 5), the coarser basal portion is exceptionally thick (about $80 \mathrm{~m}$, or more than two-thirds of the entire bed), appears to comprise several layers, and contains muddy intraclasts. The hemipelagic interval that separates this bed from Thick Pumiceous Bed III is $15.5 \mathrm{~m}$ thick at Site 790, where it contains 22 thin ash layers; it is much thinner $(<1 \mathrm{~m})$ at Site 791.

\section{Thick Pumiceous Bed III}

At Site 790 (Fig. 4), Thick Pumiceous Bed III has a total thickness of about $17 \mathrm{~m}$ and consists of a basal 1.7-m layer of gray, olive gray, and black (5Y5/1, 5Y4/1, and 5Y3/2), sand-size ash that coarsens 


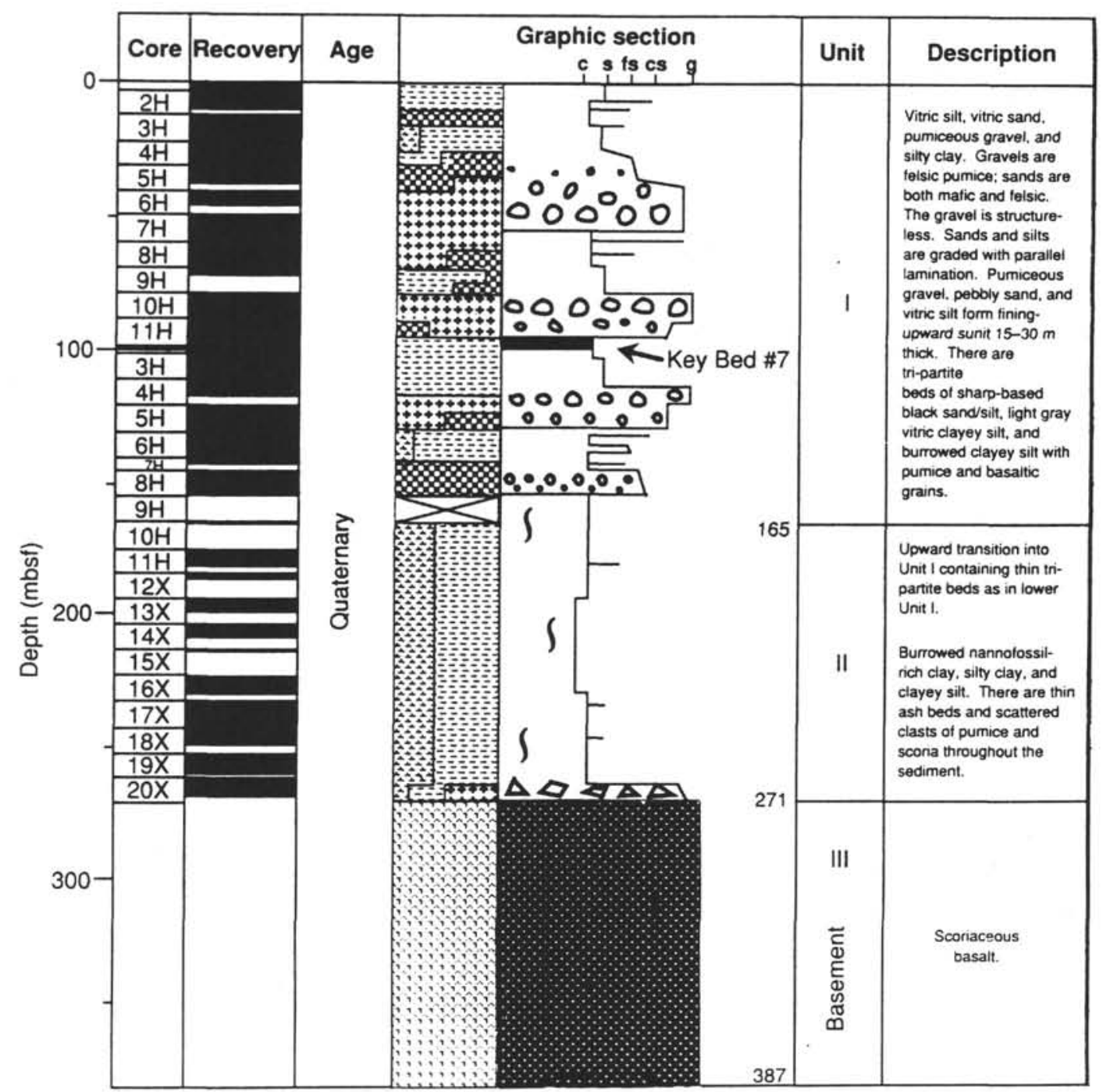

Figure 3. Lithologic units of Site 790 (Taylor, Fujioka, et al., 1990, p. 140). Thick pumiceous beds are intercalated with thin hemipelagites.

gradationally upward into a 4.5-m layer of light olive gray, olive gray, gray, and black $(5 Y 5 / 2,5 Y 5 / 1,5 Y 4 / 2$, and $5 Y 3 / 2)$, pebble-size pumiceous tephra and sand-size ash. This middle interval in turn is succeeded by $10 \mathrm{~m}$ of olive gray ( $5 \mathrm{Y} 5 / 1)$, silt-size ash. The bed is about $46 \mathrm{~m}$ thick at Site 791 (Fig. 5), where it comprises several coarse to fine layers, including one of pebble-size tephra that contains mud intraclasts in the middle of the sequence. A hemipelagic layer $<3 \mathrm{~m}$ thick between this bed and Thick Pumiceous Bed IV contains three thin ash layers.

\section{Thick Pumiceous Bed IV}

At Site 790 (Fig. 4), Thick Pumiceous Bed IV is about $37 \mathrm{~m}$ thick and consists of a basal $13 \mathrm{~m}$ of olive gray $(5 \mathrm{Y} 5 / 2)$, pebble-size pumiceous tephra and sand-size ash, overlain by $23 \mathrm{~m}$ of silt-size ash. Because of the poor recovery at Site 791, we can say little about the unit at Site 791, where it is about $146 \mathrm{~m}$ thick. A hemipelagic layer about $16 \mathrm{~m}$ thick between this layer and underlying Thick Pumiceous Bed V contains at least 29 thin ash layers.

\section{Thick Pumiceous Bed V}

The minimum thickness of this layer at Site 790, estimated at about $30 \mathrm{~m}$, is uncertain because there was no recovery from an entire core between its lowest sampled interval and the uppermost recovery from underlying Unit II. The upper part of the bed consists of an 8-m-thick, olive gray (5Y5/2), sand-size pumiceous ash and $2 \mathrm{~m}$ of silt-size ash. Recovery was much less at Site 791.

\section{Textures}

Figure 6 summarizes the results from the grain-size analyses of samples from each of the thick pumice beds. Pebble-size clasts were not included in the analyses because of sample-size limitations. The pebble-free matrices are relatively well sorted and have modes in the medium sand range. The silt-size parts of the beds are also well sorted, similar to previously sampled and described ash layers that occur close to the seafloor (Nishimura and Murakami, 1988). In addition to the dominant pumice clasts, which have water-saturated specific 


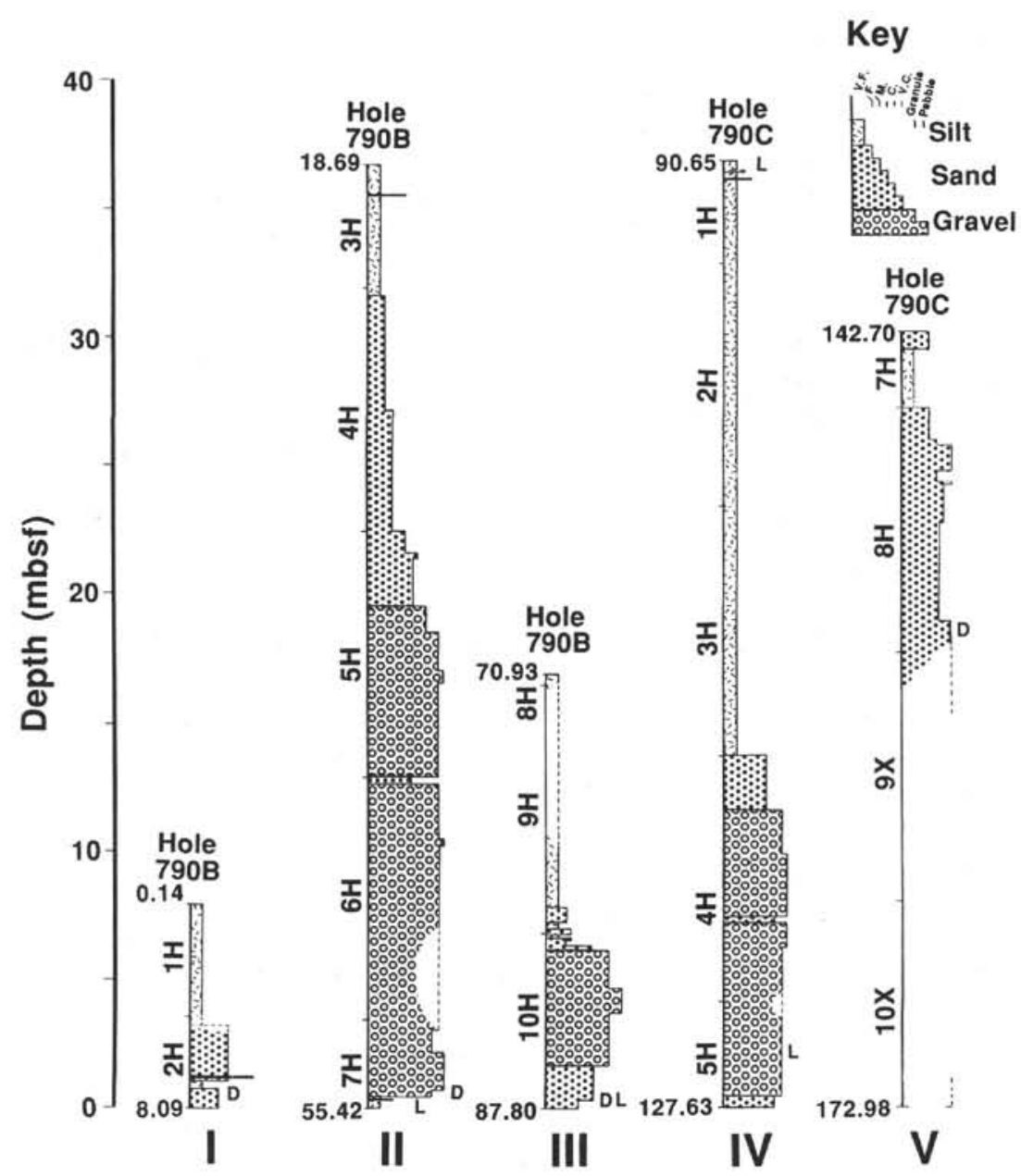

Figure 4. Lithologies of Thick Pumiceous Beds I-V in Holes 790B and 790C, based on shipboard core descriptions (Taylor, Fujioka, et al., 1990, pp. 491-526). D = dark-colored part and L= laminated part. Core numbers (e.g., $2 \mathrm{H}, 3 \mathrm{H}$, etc.) are shown beside the graphic columns.

gravities ranging from 1.26 to 1.58 , rare lithic clasts of scoriaceous andesite with specific gravities of 2.1-2.2 are also present. The ten largest pumice clasts in a core have diameters of $2-4 \mathrm{~cm}$, whereas the sizes of accompanying lithic fragments are typically $15 \%-37 \%$ as large.

\section{Grain Types}

Sand-size grains in the pumice beds are pumice, blocky glass fragments, pyroxene and feldspar mineral grains, rock fragments, and biogenic grains. The pumice grains are easily divided into two types based on vesicle morphology. The dominant type has essentially equant vesicles (Plate 2, Fig. 1), whereas vesicles in the other type are very thin and exceedingly elongate (Plate 2, Figs. 3 and 4). Biogenic components constitute minor portions of the sand fraction finer than $0.5 \mathrm{~mm}$, and include molluscan and bryozoan fragments (Plate 2, Fig. 6), and the tests of planktonic and benthic foraminifers. For example, Sample 126-790B-2H-1, 110-114 cm, from Thick Pumiceous Bed I contains bivalves and gastropoda fragments and the benthic foraminifers Bulimina aculeata, Uvigerina sp., and Quinqueloculina $\mathrm{sp}$. Shipboard smear slides show that the finer grained portion of this bed is composed primarily of fine volcanic shards with a few percent of calcareous nannofossils (Taylor, Fujioka, et al., 1990, pp. 127-220). The grain types of each thick pumiceous bed correlate well between Sites 790 and 791 (Fig. 7).

\section{Petrography and Chemistry of Pumice}

Petrographically, the pumice in these beds is two-pyroxene rhyolite (with normative quartz). Their vesicularities range from $17 \%$ to $45 \%$ (Table 1). Chemical analyses show that the pumice can be classified into Kuno's (1966) low-alkali tholeiite series. Ranges of each major element are summarized and contrasted with those of the pumice deposits of the flank site and forearc basin sites in Table 2. We also compare the chemistry of pumice from the rift basin, the flank uplift (arc), and forearc basin in plots of $\mathrm{SiO}_{2}$ vs. $\mathrm{TiO}_{2}$, alkali, and $\mathrm{K}_{2} \mathrm{O}$ (Fig. 8) and in $\mathrm{K}_{2} \mathrm{O} / \mathrm{SiO}_{2}$ plots (Fig. 9). The chemical composition of each thick pumiceous bed correlates well between Sites 790 and 791 (Fig. 10).

\section{Approximate Ages}

We have made a first approximation of the age of the thick pumiceous beds of Site 790 (Fig. 11). Our biostratigraphic time controls are the first occurrence (FO) of Emiliania huxleyi $(0.275 \mathrm{Ma})$ at a depth of $180 \mathrm{mbsf}$, and the base of the acme of this species $(0.085$ $\mathrm{Ma}$ ) at $130 \mathrm{mbsf}$ (Firth and Isiminger-Kelso, this volume). We assume that the thick pumice beds, and the thin ash layers in the hemipelagite intervals, were deposited during episodes so short as to be geologically instantaneous, whereas the hemipelagic sediment was deposited 
Table 1. Petrography of pumice of Leg 126.

\begin{tabular}{|c|c|c|c|c|c|c|c|}
\hline & $\begin{array}{c}\text { Core, } \begin{array}{c}\text { section, } \\
\text { interval }(\mathrm{cm})\end{array} \\
\end{array}$ & $\begin{array}{c}\text { Vesicularity } \\
(\%)\end{array}$ & $\begin{array}{l}P I \\
(\%)\end{array}$ & $\begin{array}{l}\text { Cpx } \\
(\%)\end{array}$ & $\begin{array}{l}\text { Opx } \\
(\%) \\
\end{array}$ & $\begin{array}{l}\mathrm{Hb} \\
(\%)\end{array}$ & $\begin{array}{c}\text { Groundmass } \\
(\%) \\
\end{array}$ \\
\hline $126-$ & $790 \mathrm{~B}-2 \mathrm{H}-2,10-20$ & 25 & 0.33 & 0.33 & 0.50 & - & 98.84 \\
\hline & $790 \mathrm{~B}-7 \mathrm{H}-2,34-38$ & 23 & 1.00 & 1.00 & 0.66 & - & 97.34 \\
\hline & $790 \mathrm{~B}-10 \mathrm{H}-1,70-140$ & 40 & 0.66 & + & + & - & 99.34 \\
\hline & $790 \mathrm{C}-5 \mathrm{H}-1,73-77$ & 45 & 0.33 & + & - & - & 99.67 \\
\hline & $790 \mathrm{C}-8 \mathrm{H}-6,116-120$ & 20 & 0.66 & 0.50 & 0.50 & - & 98.34 \\
\hline & $791 \mathrm{~A}-3 \mathrm{H}-3,20-100$ & 40 & 0.33 & - & 0.30 & - & 99.37 \\
\hline & $791 \mathrm{~A}-10 \mathrm{H}-5,53-96$ & 30 & 0.20 & 0.33 & 0.33 & - & 99.14 \\
\hline & $791 \mathrm{~A}-22 \mathrm{H}-2,45-50$ & 40 & 0.66 & 0.20 & 0.33 & $\cdot$ & 98.81 \\
\hline & $791 A-28 X-1,66-70$ & 17 & 0.50 & - & 0.20 & - & 99.30 \\
\hline & $788 \mathrm{C}-1 \mathrm{H}-1,34-36$ & 40 & 0.33 & + & $\cdot$ & $\cdot$ & 99.67 \\
\hline & $788 \mathrm{C}-14 \mathrm{H}-4,70-72$ & 30 & 0.20 & $\cdot$ & - & $\cdot$ & 99.80 \\
\hline & $788 \mathrm{C}-22 \mathrm{H}-1,47-49$ & 20 & 0.20 & + & + & - & 99.80 \\
\hline $125-$ & $785 \mathrm{~A}-1 \mathrm{H}-3,14-17$ & 25 & 0.33 & - & + & - & 99.67 \\
\hline & $785 A-1 H-5,11-14$ & 45 & 0.10 & $\cdot$ & 0.10 & $\cdot$ & 99.80 \\
\hline & $785 \mathrm{~A}-2 \mathrm{H}-5,10-12$ & 45 & 0.33 & - & 0.20 & $\cdot$ & 99.47 \\
\hline $126-$ & $793 \mathrm{~A}-1 \mathrm{H}-3,50-52$ & 35 & 0.66 & 0.50 & 0.50 & - & 98.34 \\
\hline & $793 \mathrm{~A}-1 \mathrm{H}-3,50-52$ & 50 & 0.33 & 0.10 & 0.10 & $\cdot$ & 99.47 \\
\hline & $793 \mathrm{~A}-2 \mathrm{H}-5,42-44$ & 25 & 0.66 & 0.20 & 0.33 & + & 98.81 \\
\hline & $793 A-2 H-5,42-44$ & 35 & 0.33 & 0.66 & 0.50 & - & 98.51 \\
\hline & $793 \mathrm{~A}-3 \mathrm{H}-5,70-72$ & 20 & 1.00 & - & + & - & 99.00 \\
\hline & $793 \mathrm{~A}-5 \mathrm{H}-7,40-42$ & 35 & 1.00 & - & + & - & 99.00 \\
\hline
\end{tabular}

Table 2. Summary of ranges in major-oxide contents (\%) of pumice samples from Leg 126.

\begin{tabular}{c|c|c|c|c|c|c}
\hline & Backarc Pumice & \multicolumn{2}{|c|}{ Arc Pumice } & \multicolumn{3}{c}{ Forearc Pumice } \\
\cline { 2 - 6 } & Sites 790, 791 & \multicolumn{2}{|c|}{ Site 788 } & \multicolumn{2}{c}{ Site 793 } & \multirow{2}{*}{ Site 785 } \\
\cline { 3 - 6 } & & Quaternary & Pliocene & Upper Quat. & Middle Quat. & \\
\hline $\mathrm{SiO}_{2}$ & $71.4-80.1$ & $75.8-78.8$ & $70.7-77.5$ & $69.4-75.7$ & $73.5-77.2$ & $71.5-77.6$ \\
$\mathrm{Al}_{2} \mathrm{O}_{3}$ & $11.6-15.0$ & $11.9-13.6$ & $11.6-13.8$ & $13.2-14.3$ & $12.8-14.3$ & $12.1-14.1$ \\
$\mathrm{TiO}_{2}$ & $0.2-0.8$ & $0.4-0.5$ & $0.5-0.8$ & $0.3-0.8$ & $0.4-0.5$ & $0.3-1.0$ \\
$\mathrm{Fe}_{2} \mathrm{O}_{3}$ & $2.3-5.2$ & $2.8-3.3$ & $3.6-5.4$ & $1.9-5.6$ & $2.8-3.4$ & $2.6-4.9$ \\
$\mathrm{MgO}$ & $0.3-1.5$ & $0.6-0.7$ & $0.9-2.2$ & $0.6-1.6$ & $0.5-0.6$ & $0.4-1.7$ \\
$\mathrm{CaO}$ & $1.8-4.4$ & $2.4-3.4$ & $2.8-4.2$ & $3.1-4.8$ & $2.8-3.7$ & $2.7-5.0$ \\
$\mathrm{Na}_{2} \mathrm{O}$ & $1.4-2.9$ & $1.5-2.3$ & $1.8-2.3$ & $2.7-3.1$ & $2.0-2.8$ & $2.0-2.4$ \\
$\mathrm{~K}_{2} \mathrm{O}$ & $0.5-1.3$ & $0.9-1.0$ & $0.7-1.4$ & $0.8-1.4$ & $0.9-1.0$ & $0.8-1.3$ \\
\hline
\end{tabular}

slowly at fairly constant rates $(59 \mathrm{~mm} / \mathrm{k}$.y. in the interval between 180 and $130 \mathrm{mbsf}$, and $150 \mathrm{~mm} / \mathrm{k} . \mathrm{y}$. for the column above $130 \mathrm{mbsf}$ ). This yields ages of $1,31,61,67$, and 131 ka for Thick Pumiceous Beds I, II, III, IV, and V, respectively (Fig. 11), with only Thick Pumiceous Bed V deposited during the period of slower sedimentation. Alternatively, if the increase in hemipelagic sedimentation rate of $150 \mathrm{~mm} / \mathrm{k} . \mathrm{y}$. occurred between Thick Pumiceous Beds V and IV, Thick Pumiceous Bed V would have an age of only $102 \mathrm{ka}$. The correlation of the thick pumiceous beds between Sites 790 and 791 is shown in Figure 12; we assume that the thick pumiceous beds at Site 791 are the same ages as those at Site 790.

\section{Pumice Deposits of the Arc (Eastern Rift Flank)}

The sedimentary succession of arc Site 788 is dominated by coarse clastic deposits of rhyolitic pumice (Fig. 13). Unit II is early Pliocene in age (4.8-3.8 Ma), and Unit I is Pliocene to Quaternary (>3.8 Ma). The uppermost, 30 -m thick interval is biostratigraphically separated from the others by an unconformity. Below the hiatus, the age of these pumiceous gravel beds is somewhere between 2.85 and $2.35 \mathrm{Ma}$, depending upon the actual sedimentation rate, which is not well constrained (Taylor, Fujioka, et al., 1990, pp. 221-314). The gravels immediately above the hiatus were biostratigraphically dated at $0.275 \mathrm{Ma}$; the age of the sediments at the surface is not known. Recovery from Unit II was poor, and so we present descriptions and analyses of pumices only from Unit I.

Unit I is composed principally of poorly sorted ash and pumiceous tephra of sand to pebble sizes (Plate 1, Fig. 3). Sand and silt-size vitric ash is very rare in the sequence, in which hemipelagites and pelagites are virtually absent. The pumice clasts are colored olive gray (5Y4/2) to light olive gray $(5 \mathrm{Y} 5 / 2)$, but in the Quaternary layer some are discolored and oxidized to various shades of brown and yellow, suggesting that the surface deposits resided for some time at the seafloor, where they were subjected to oxidation and winnowing.

Shipboard grain-size descriptions subdivide the unit into four intervals with coarsening-upward trends $30-50 \mathrm{~m}$ thick. It is possible that some of the cycles may actually include composite layers. The uppermost cycle corresponds to the Quaternary pumice deposits, and 


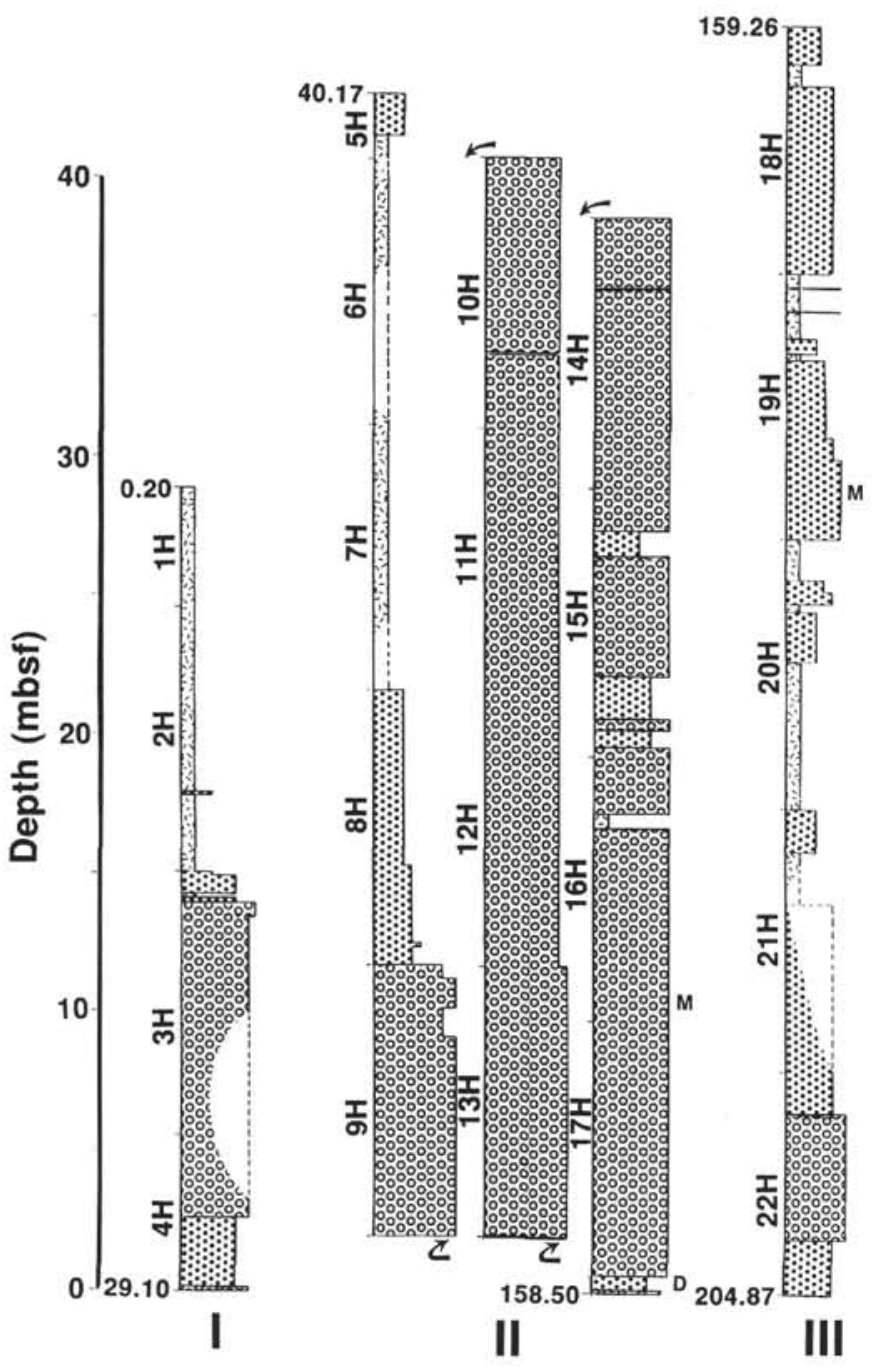

Figure 5. Lithologies of Thick Pumiceous Beds I-III in Hole 791A, based on shipboard core descriptions. The key is the same as in Figure 4. M=mud intraclasts.

the lower cycles to the Pliocene ones. Sand/granule/pebble ratios range from $5 / 5 / 90$ to $90 / 10 / 0$ in individual cores, with a mean of $25 / 30 / 45$. Lithic clasts of andesitic scoria, only $15 \%-30 \%$ as large as the pumice fragments, comprise less than $1 \%$ of the total sediments.

Petrologically, the pumices at Site 788 are two-pyroxene rhyolites (Table 1); chemically, they are arc tholeiites. The range of major-oxide contents of the pumice samples are summarized separately for the Pliocene and the uppermost Quaternary deposits in Table 2. The $\mathrm{K}_{2} \mathrm{O}$ contents of the Pliocene deposits are higher than those of the Quaternary samples from this site as well as those from the rift basin. Most of the pumice clasts from the Quaternary bed of Unit I at Site 788 are chemically similar to the thick pumiceous beds of the Sumisu Rift, although also present are some resedimented pumice clasts of dacitic $\left(\mathrm{low}-\mathrm{SiO}_{2}\right)$ composition and very high $\mathrm{K}$ contents that were probably derived from the lower sequence of Pliocene age (Fig. 9). Analyses of these clasts were not used to determine the ranges of major element abundances given in Table 2. The $\mathrm{K}_{2} \mathrm{O}$ vs. $\mathrm{SiO}_{2}$ plots of Figure 9 show that the pumice deposits of Site 788 may be correlative with Thick Pumiceous Beds I, II, IV, and $\mathrm{V}$ of Sites 790 and 791; Thick Pumiceous Bed III has lower $\mathrm{K}_{2} \mathrm{O}$ contents.

\section{Forearc Pumice Deposits}

Here, we briefly describe pumice deposits recovered from Legs 126 (Sites 787, 792, and 793) and 125 (Site 785). At Site 793 (Fig. 14), the uppermost $14.5 \mathrm{~m}$ of the sequence is a gravelly deposit of dark gray $(5 \mathrm{Y} 4 / 1, \mathrm{~N} 3)$ pumice that correlates biostratigraphically with the thick pumiceous beds of the Sumisu Rift. Sand contents are low, ranging from $10 \%$ to $30 \%$. The middle part of the Quaternary sequence (Subunit IA and upper part of Subunit IB) contains a 20-m-thick interval of possible debris-flow deposits with a mixed assemblage of dark gray (5Y4/1), pebble-size pumice and varicolored intraclasts of nannofossil ooze (Taylor, Fujioka, et al., 1990, pp. 315-403). Petrologically, the pumice from the uppermost bed is hornblende-two-pyroxene rhyolite, and that from the debrite is two-pyroxene rhyolite. The ranges in major-oxide contents for both beds are given in Table 2; they are very similar to those of the thick pumiceous beds of the Sumisu Rift.

At Site 785 , located in the forearc basin $70 \mathrm{~km}$ east-northeast of Tori Shima Island (Fig. 1), the uppermost 3-m-thick layer consists of nannofossil ooze, which overlies thick pumice deposits that were penetrated only down to $66.8 \mathrm{mbsf}$ but are probably more than $100 \mathrm{~m}$ thick (Fryer, Pearce, Stokking, et al., 1990). Calcareous nannofossil biostratigraphy shows that the base of the surface nannofossil ooze is older than the $\mathrm{CN} 15 / \mathrm{CN} 14 \mathrm{~b}$ boundary $(>0.275 \mathrm{Ma})$, and so the thick pumice deposits of Site 785 are older than the thick pumiceous beds of the Sumisu Rift. The pumice clasts are petrologically two-pyroxene rhyolites (Table 1). Table 2 and Figure 9 show that the pumice from these beds are chemically similar to the pumice deposits of the rift basin, but they contain slightly more $\mathrm{K}_{2} \mathrm{O}$.

At Site 792, a complete sequence records the volcanic activity of the arc during middle to late Quaternary time (see the ash-layer table of Taylor, Fujioka, et al., 1990, pp. 221-314). The sequence contains no beds of coarse pumice, but thin ash layers are intercalated throughout, some of which are possibly correlative with the thick pumiceous beds of the Sumisu Rift. We estimate that ash-producing episodes ranged in frequency from 120 to 350 per m.y. or more (Fujioka et al., this volume).

Site 787 is located in the Aoga Shima Canyon east of Aoga Shima Island (Taylor and Smoot, 1984). The Quaternary sediment here (Unit I; 0-21.7 mbsf) is dark gray (N3) to black (N2) sandy pumice and scoria admixed with molluscan and bryozoan fragments (Taylor, Fujioka, et al., 1990, pp. 63-96). These deposits are canyon fill remobilized from the shallower surroundings and were not analyzed in detail.

\section{ORIGIN AND DEPOSITIONAL PROCESSES OF PUMICE DEPOSITS}

The thick pumiceous beds of the Sumisu Rift, separated from one another by hemipelagic intervals, record five episodes of input by explosive volcanism in the period after $0.15 \mathrm{Ma}$. Their chemistry indicates that they are products of arc volcanism that belong to Kuno's (1966) low-alkali tholeiite series. Rocks from the frontal-arc volcanos in the northern Izu-Bonin Arc also belong to this series, except for those from the Beyonesu Rocks of the Myojin Sho (Yuasa and Tamaki, 1982). Furthermore, the Sumisu Rift pumices have lower concentrations of $\mathrm{Rb}, \mathrm{Zr}, \mathrm{Nb}, \mathrm{Ce}$, and $\mathrm{Y}$ relative to $\mathrm{SiO}_{2}$ than do rift rhyolite (Taylor, Fujioka, et al., 1990, pp. 97-126; Gill et al., this volume).

Five lines of evidence indicate that the thick pumiceous beds of the Sumisu Rift were deposited by sediment gravity flows:

1. They each display a single upward-fining sequence.

2. Both coarser and finer grained parts of the beds are relatively well sorted.

3. The deposits include biogenic grains (molluscan and bryozoan fragments and foraminifer tests in the coarser part and calcareous nannofossils in the finer part) that must have been incorporated by sediment gravity flows from the underlying substrate (Carey and Sigurdsson, 1980).

4. Thick Pumiceous Beds II and III contain mud intraclasts at Site 791.

5. Each pumice bed is several times thicker at Site 791 than at Site 790 , which suggests a syntectonic smoothing of the rift-basin 
Site 790
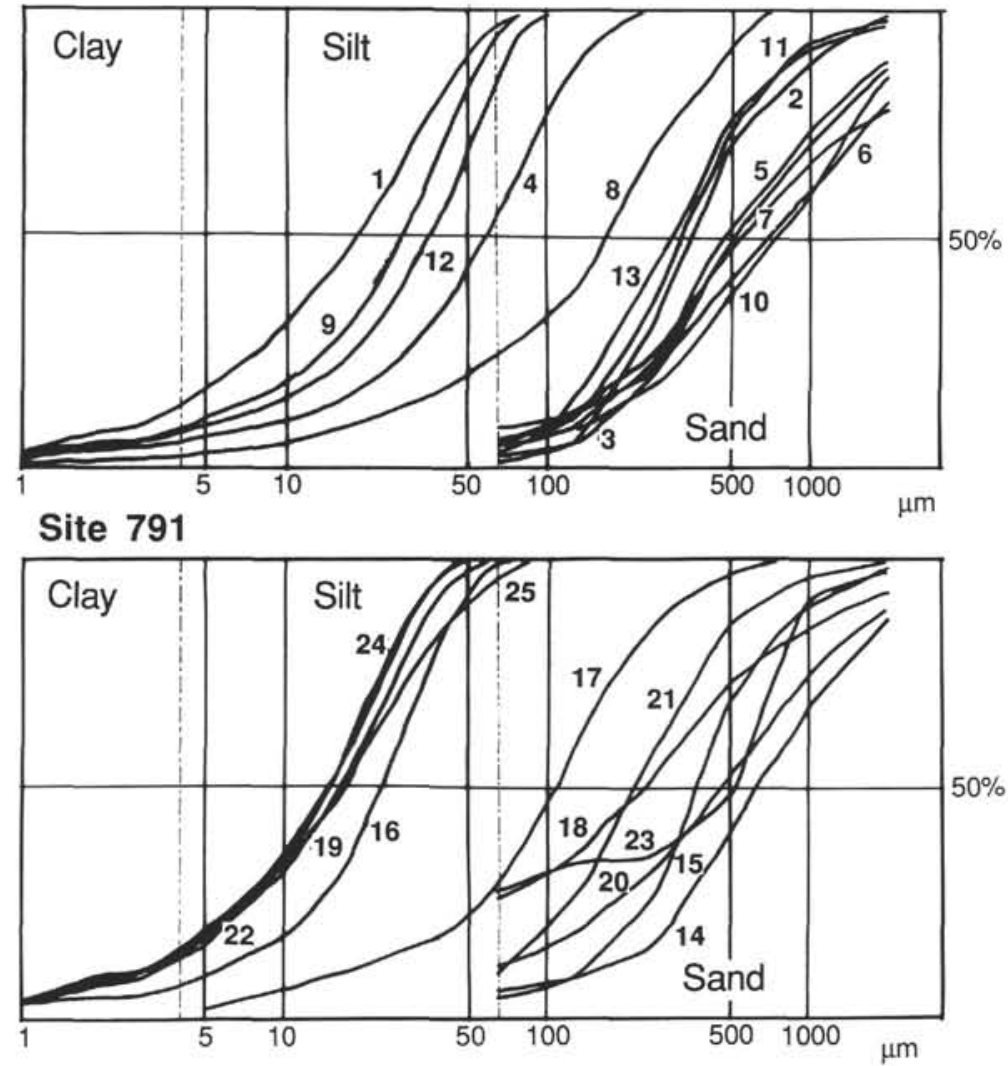

Figure 6. Grain-size distributions of the thick pumiceous beds at Sites 790 and 791 . Numbers $1-25$ on the figure represent the following samples: $1=$ Sample $126-790 \mathrm{~B}-1 \mathrm{H}-2,37-41 \mathrm{~cm}$ (1.9 mbsf); 2 =Sample 126-790B-2H-1, 110-114 cm (5.6 mbsf); $3=$ Sample 126-790B-2H $2,10-20 \mathrm{~cm}$ (6.1 mbsf); 4 = Sample 126-790B-4H-2, 78-82 cm (25.8 mbsf); 5 = Sample 126-790B-5H-5, 43-47 cm (39.4 mbsf); $6=$ Sample 126-790B-7H-2, 34-38 cm (53.9 mbsf); 7 = Sample 126-790B-10H-1, 70-140 cm (81.7 mbsf); 8 = Sample 126-790B-10H-4, $102-106 \mathrm{~cm}$ ( $86.5 \mathrm{mbsf}) ; 9=$ Sample $126-790 \mathrm{C}-3 \mathrm{H}-6,28-32 \mathrm{~cm}$ (112.0 mbsf); $10=$ Sample 126-790C-5H-1, 73-77 cm (124.2 mbsf); 11 = Sample 126-790C-5H-3, 7-11 cm (126.6 mbsf); 12 = Sample 126-790C-7H-2, 60-64 cm (144.8 mbsf); $13=$ Sample 126-790C-8H-6, $116-120 \mathrm{~cm}$ (154.4 mbsf); $14=$ Sample 126-791A-3H-3, 20-100 cm (17.2 mbsf); $15=$ Sample 126-791A-4H-3, 6-10 cm (26.6 mbsf); 16 = Sample 126-791A-7H-2, 30-35 cm (53.8 mbsf); 17 = Sample 126-791A-8H-3,38-42 cm (65.0 mbsf); $18=$ Sample 126-791A$10 \mathrm{H}-5,53-96 \mathrm{~cm}$ (87.5 mbsf); $19=$ Sample 126-791 A-20H-4, 28-32 cm (181.8 mbsf); 20 $=$ Sample 126-791A-22H-2, 45-50 cm (198.9 mbsf); 21 = Sample 126-791A-22H-6, 28-32 cm (202.7 mbsf); 22 = Sample 126-791A-25X-1, 28-32 cm (217.4 mbsf); 23 = Sample 126-791A-28X-2, 66-70 cm (246.7 mbsf); 24 = Sample 126-791A-33X-1, 60-64 cm (296.9 mbsf); and 25 = Sample 126-791 A-34X-1, 43-48 cm (304.4 mbsf).

floor by sediment gravity flows. At present, Site 790 is $40 \mathrm{~m}$ shallower than Site 791.

Each thick pumice bed in the rift has an uppermost thick, finegrained ash layer. This suggests that the explosive eruptions that produced the massive pumice deposits were submarine, because the finer grained products of subaerial eruptions tend to be sorted out and deposited far from the source volcano. Submarine eruptions input both finer grained ash and coarser pumice into the seawater. Hot pumice clasts sink immediately after cooling, but cold ones sometimes float for a long time (Whitham and Sparks, 1986). Fragments of highly elongated vesiculated pumice similar to those described here (Plate 2, Figs. 3 and 4) have been reported from deep-water sources (Kato, 1987). Furthermore, the pronounced size differences of the predominant pumice clasts and the rare associated lithic clasts in the flank site deposits suggest that the clasts of both sizes settled together through seawater columns at the same velocities, in a fashion similar to that determined for similar Miocene-Pliocene deposits in Japan studied by Fiske and Cashman (1989).

We can speculate on the sources and transport paths of the rift-basin pumice deposits by examining the modern bathymetry (Fig. 2), because the deposits are very young $(<0.15 \mathrm{Ma})$. Three submarine calderas are present along the eastern rift flank: Sumisu, Minami-Sumisu (Daisan Sumisu Knoll), and Tori Shima (Fig. 1). Minami-Sumisu Caldera is a likely source because pumice from it is chemically similar to pumice from Thick Pumiceous Bed I (Taylor, Fujioka, et al., 1990, pp. 97-126; Gill et al., this volume). At present, a ridge barrier of small basaltic and dacitic cones arranged en echelon separates the north and south basins of the Sumisu Rift, and no path exists through the Kita (north) Sumisu Basin from Sumisu and Minami-Sumisu calderas to the Minami (south) Sumisu Basin. The K-Ar age of two rock samples from the ridge barrier are 255 and $276 \mathrm{ka}$ (Hochstaedter et al., 1990); 


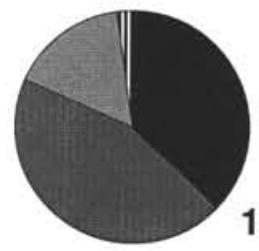

Thick Pumiceous Bed I

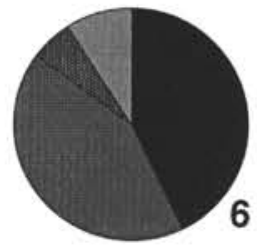

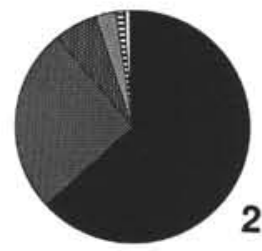

Thick Pumiceous Bed II

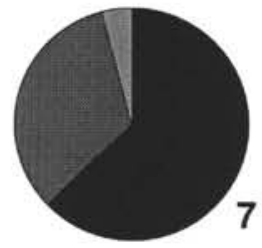

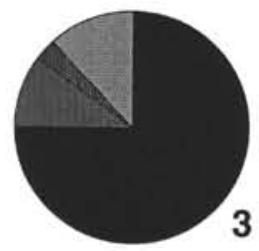

Thick Pumiceous Bed III

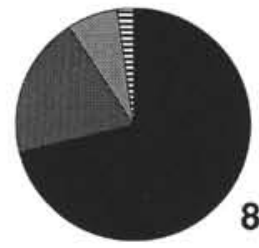

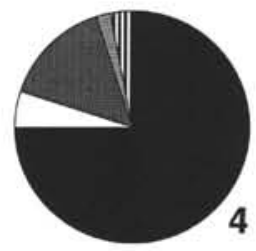

Thick Pumiceous Bed IV

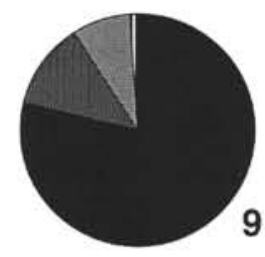

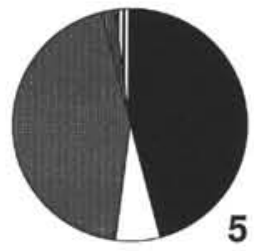

Thick Pumiceous Bed V

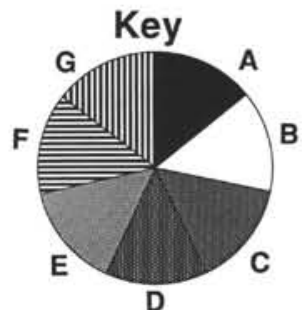

Figure 7. Grain types of the 0.5-1 mm fractions from the coarse portions of the thick pumiceous beds of the Sumisu Rift. A= white-colored pumice; $\mathrm{B}=$ highly vesiculated, white-colored pumice; $\mathrm{C}=$ pumice with highly elongated vesicles; $\mathrm{D}=$ gray-colored pumice; $\mathrm{E}=$ olive to brown-colored glass; $\mathrm{F}=$ crystals; and $\mathrm{G}=$ rock fragments. 1 = Sample 126-790B-2H-1, 110-114 cm (5.6 mbsf); $2=$ Sample 126-790B-5H-5, $43-47 \mathrm{~cm}$ (39.4 mbsf); 3 = Sample 126-790B-10H-1, 70-140 cm (82.0 mbsf); 4 = Sample 126-790C-5H-3, 7-11 cm (132.2 mbsf); 5 = Sample 126-790C-8H-6, 116-120 cm (154.4 mbsf); 6 = Sample 126-791A-3H-3, 20-100 cm (17.6 mbsf); 7 = Sample 126-791A-10H-5, 53-96 cm (87.8 mbsf); 8 = Sample 126-791A-22H-2, 45-50 cm (198.9 mbsf); and 9 = Sample 126-791A-28X-1, 66-70 $\mathrm{cm}$ (246.7 mbsf).

these ages are older than that of the lowermost thick pumice bed of the rift (131 ka). The foot of the eastern flank of the ridge has no large, prismatic, talus-like deposits of volcanic debris, which excludes the possibility that gravity flows could have passed over the top of the flank crest. An unrestricted route into the basin lies northwestward from Tori Shima Caldera, which, with its associated vents, is another probable source. We have no sample from this caldera, however, and basaltic and andesitic rocks are reported from the active volcano on Tori Shima Island (Tsuya, 1937; Nishimura et al., 1988; Takada and Yuasa, 1990). Chemical compositions alone cannot identify the source.

\section{TEMPORAL AND AREAL DISTRIBUTION OF PUMICE DEPOSITS}

Age data have established a correlation of the thick pumice deposits of the backarc, arc, and forearc, and the chemical compositions of the beds at these localities are concentrated in rather small areas in oxideoxide plots (Fig. 8). The older (Pliocene) pumiceous beds of Site 788 pre-date the backarc rifting have slightly higher $\mathrm{K}_{2} \mathrm{O}$ contents than the Quaternary rift-basin pumices, but the uppermost $30 \mathrm{~m}$ at the flank site correlates biostratigraphically and is chemically similar to those of the Sumisu Rift (Taylor, Fujioka, et al., 1990, pp. 407-413).

In summary, the regional pumice-producing volcanism started in the early Pliocene and continues to the present in the arc area of the Sumisu Jima and Tori Shima islands. At Site 788, the hiatus between the Pliocene and Quaternary pumice deposits suggests a break in pumice production from the late Pliocene to the middle Quaternary $(2.35-0.275 \mathrm{Ma})$, a period that corresponds to the initial stage of backarc rifting. However, the almost complete Quaternary sequences at forearc Sites 792 and 793 suggest that pumice-producing volcanism occurred continuously with variable intensities even during this period.

Our first approximation of ages for the thick pumiceous beds of the Sumisu Rift indicates pumice-producing episodes of rhyolitic volcanism about $1,31,61,67$, and $131 \mathrm{ka}$. If the third and fourth events are regarded as close enough in time to represent two phases of a single episode, and if the option of a higher sedimentation rate is exercised for the interval of hemipelagite sedimentation between the deposition of the fourth and fifth beds, the period between eruptive episodes is about 30 k.y. Site 792, $100 \mathrm{~km}$ away from Sumisu Jima Island and 200 km away from Tori Shima Island, contains a complete sequence, dated $<1.1 \mathrm{Ma}$, with more than a hundred ash layers (Taylor, Fujioka, et al., 1990, pp. 221-314), which may be thin, finer grained ash equivalents of the thick pumiceous beds in the Sumisu Rift. The abundant ash layers of Site 792 record a fairly continuous production of volcanic materials since 1.1 Ma. Precise correlation of the ash layers in the forearc and backarc sites based on stratigraphic, petrologic, and chemical data is one of the most important future areas of study to reveal and explain the nature of volcanism in this arc.

\section{CONCLUSIONS}

The thick sediment fill in the Sumisu backarc rift consists of a lower sequence of hemipelagites with thin ash layers, and an upper sequence of five pumiceous beds, each several tens of meters to over $100 \mathrm{~m}$ thick, intercalated with thin hemipelagites. This upper sequence was rapidly deposited since $0.15 \mathrm{Ma}$, principally during pumice-producing episodes of rhyolitic volcanism that occurred approximately $1,31,61,67$, and $131 \mathrm{ka}$. These pumices are two-pyroxene rhyolites, indicating that their sources were arc volcanos. Their sequences, grain types, and textures indicate that they were deposited by submarine sediment gravity flows, during and immediately after major eruptions along the arc that were probably submarine.

\section{ACKNOWLEDGMENTS}

We would like to thank K. Marsaglia, R. N. Hiscott, J. Firth, M. Koyama, B. Taylor, T. R. Janecek, M. Yuasa, Y. Okamura, A. Colella, $\mathrm{K}$. Tazaki, and A. Klaus for extensive and fruitful discussions regarding pumice deposits. We are very grateful to $\mathrm{M}$. T. Ledbetter for reviewing the manuscript.

\section{REFERENCES}

Brown, G., and Taylor, B., 1988. Sea-floor mapping of the Sumisu Rift, IzuOgasawara (Bonin) Island Arc. Bull. Geol. Surv. Jpn., 39:23-38.

Carey, S. N., and Sigurdsson, H., 1984. A model of volcanogenic sedimentation in marginal basins. In Kokelaar, B. P., and Howells, M. F. (Eds.), Margin Basin Geology. Spec. Publ., Geol. Soc. London, 37-58. 

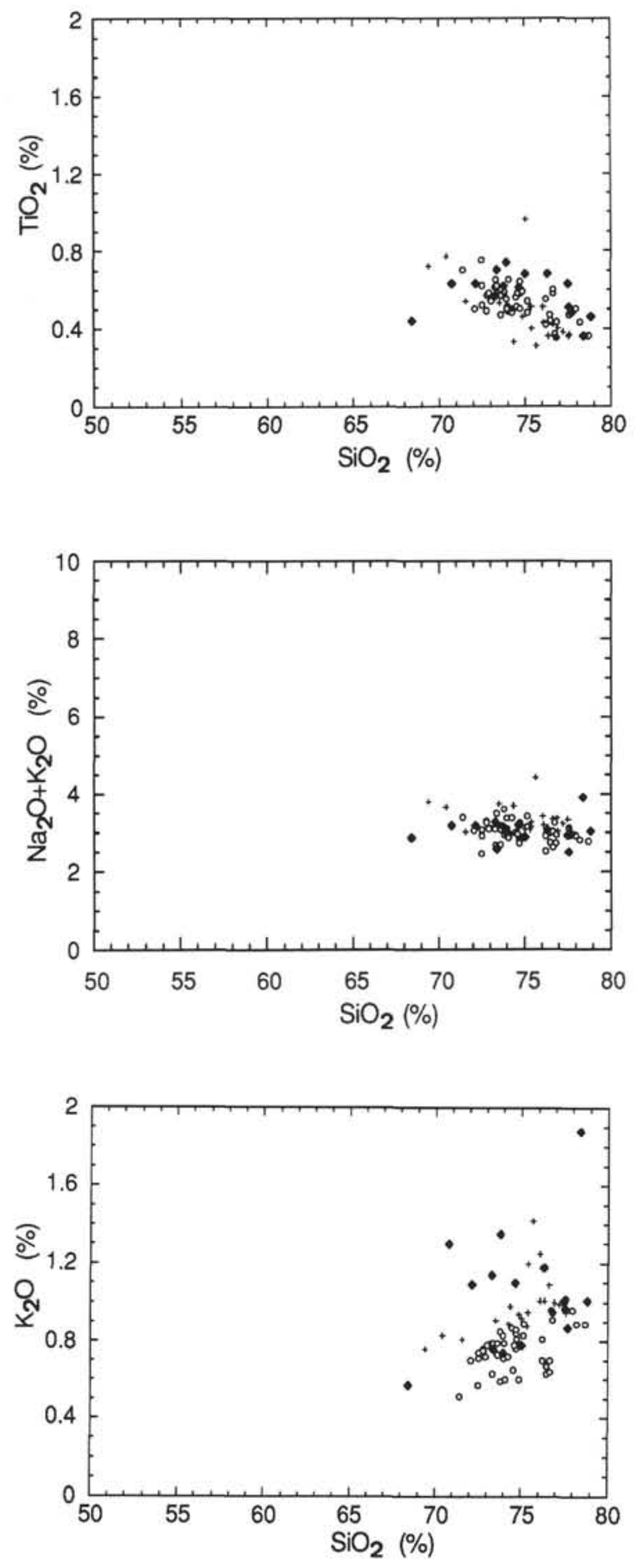

Figure 8. Plots of $\mathrm{TiO}_{2}$, alkali $\left(\mathrm{Na}_{2} \mathrm{O}+\mathrm{K}_{2} \mathrm{O}\right)$, and $\mathrm{K}_{2} \mathrm{O}$ vs. $\mathrm{SiO}_{2}$ of pumices of backarc (Sites 790 and 791), arc (Site 788), and forearc (Site 785) sites. Open circles = backarc, filled diamonds = arc, and plus signs $=$ forearc.
1980. The Roseau Ash: deep-sea tephra deposits from a major eruption on Dominica, Lesser Antilles Arc. J. Volcanol. Geothermal Res., 7:67-86.

Fiske, R. S., and Cashman, K. V., 1989. Submarine fallout deposit in the Shirahama Group (Mio-Pliocene), Japan. Abstr. Vol., Int. Assoc. Volcanol. Chem. Earth's Interior, Gen. Assem., Santa Fe, New Mexico, No. 92.

Fryer, P., Pearce, J. A., Stokking, L. B., et al., 1990. Proc. ODP, Init. Repts., 125: College Station, TX (Ocean Drilling Program).

Hochstaedter, A. G., Gill, J. B., Kusakabe, M., Newman, S., Pringle, M., Taylor, B., and Fryer, P., 1990. Volcanism in the Sumisu rift. I. Major element, volatile and stable isotope geochemistry. Earth Planet. Sci. Lett., 100:179-194.

Honza, E., and Tamaki, K., 1985. The Bonin Arc. In Nairn, A.E.M., Stehli, F. G., and Uyeda, S. (Eds.), The Ocean Basins and Margins (Vol. 7): The Pacific Ocean: New York (Plenum), 459-502.

Karig, D. E., and Moore, G. F., 1975. Tectonically controlled sedimentation in marginal basins. Earth Planet. Sci. Lett., 26:233-238.

Kato, Y., 1987. Woody pumice generated with submarine eruption. J. Geol. Soc. Jpn., 93:11-20.

Klein, G. deV., 1985. The control of depositional depth, tectonic uplift, and volcanism on sedimentation processes in the back-arc basins of the western Pacific Ocean. J. Geol., 93:1-25.

Kuno, H., 1966. Lateral variation of basalt magma type across continental margins and island arcs. Bull. Volcanol., 29:195-222.

Murakami, F., 1988. Structural framework of the Sumisu Rift, Izu-Ogasawara Arc. Bull. Geol. Surv. Jpn., 39:1-21.

Murakami, F., and Ishihara, T., 1985. Submarine calderas discovered in the northern part of the Ogasawara Arc. Gekkan Chikyu, 7:638-646.

Niino, H., Kumagori, T., Tsuya, H., Morimoto, R., Ossaka, G., Hamaguchi, H., Tatsumoto, M., Matsue, Y., Komaki, Y., Arihasa, C., Ebina, K., and Takagi, K., 1953. Report of the submarine eruption of Myojin-Sho. $J$. Tokyo Univ. Fish., 40 (Spec. No.):52.

Nishimura, A., and Murakami, F., 1988. Sedimentation in the Sumisu Rift, Izu-Ogasawara Arc. Bull. Geol. Surv. Jpn., 39:39-61.

Nishimura, A., Yamazaki, T., Yuasa, M., Mita, N., and Nakao, S., 1988. Bottom sample and heat flow data of Sumisu and Torishima Rifts, Izu-Ogasawara Island Arc. Geol. Surv. Jpn., Mar. Geol. Map Ser, 31 (scale 1:200,000).

Takada, A., and Yuasa, M., 1990. Hachijo-Jima. Geol. Surv. Jpn., Geol. Map (scale 1:200,000).

Taylor, B., Brown, G., Fryer, P., Gill, J., Hochstaedter, A., Hotta, H., Langmuir, C., Leinen, M., Nishimura, A., and Urabe, T., 1990. ALVIN-SeaBeam studies of the Sumisu Rift, Izu-Bonin Arc. Earth Planet. Sci. Lett., 100:127-147.

Taylor, B., Fujioka, K., et al., 1990. Proc. ODP, Init. Repts., 126: College Station, TX (Ocean Drilling Program).

Taylor, B., and Smoot, N. C., 1984. Morphology of Bonin fore-arc submarine canyons. Geology, 12:724-727.

Tsuya, H., 1937. On the volcanism of the Huzi Volcanic Zone, with special reference to the geology and petrology of Idu and the Southern Islands. Tokyo Daigaku Jishin Kenkyusho Iho, 15:215-357.

Whitham, A. G., and Sparks, R.S.J., 1986. Pumice. Bull. Volcanol., 48:209-223.

Yuasa, M., and Tamaki, K., 1982. Basalt from Minami-Iwojima Island, Volcano Islands. Bull. Geol. Surv. Jpn., 33:531-540.
Date of initial receipt: 20 December 1990

Date of acceptance: 1 August 1991

Ms 126B-115 

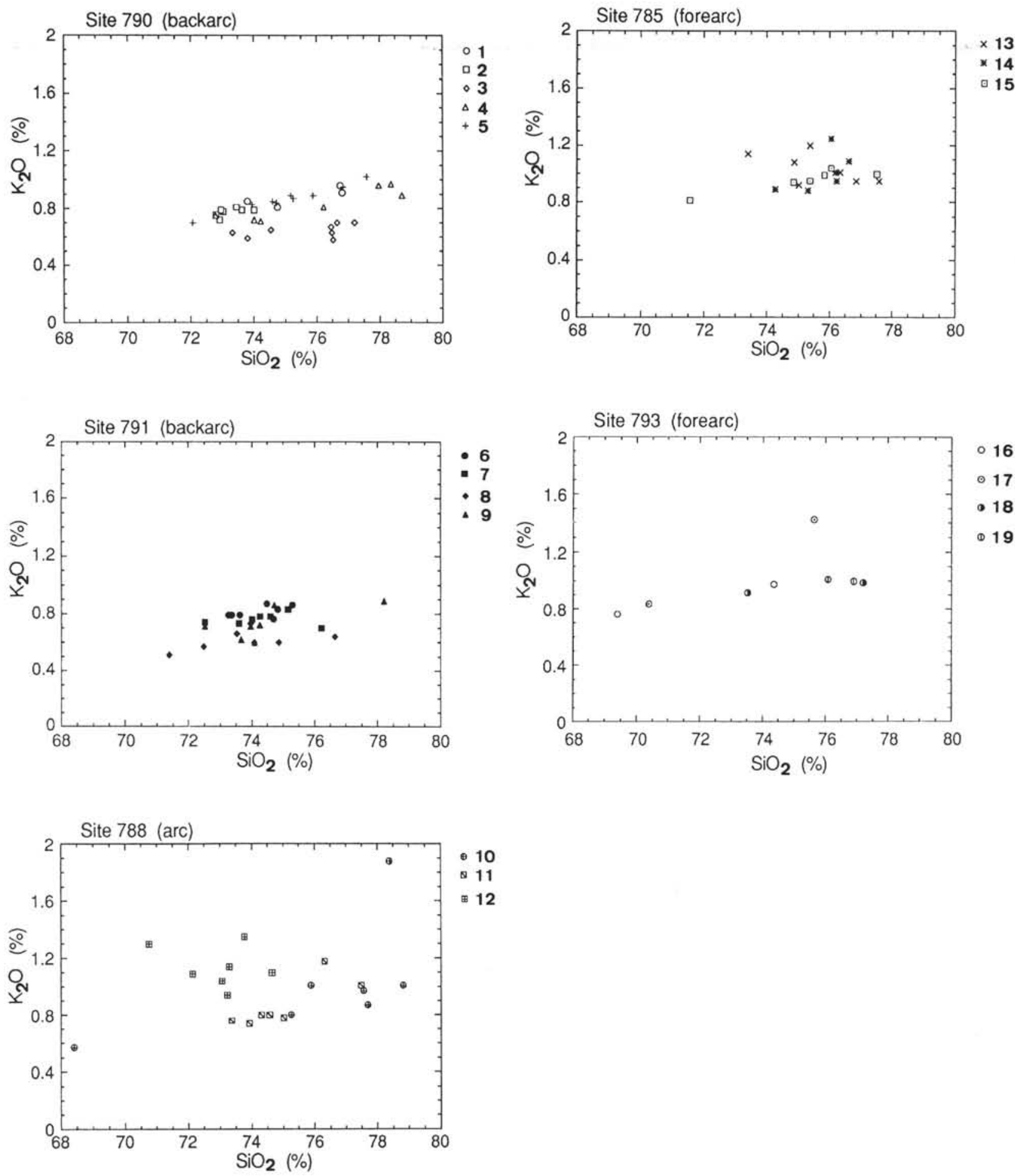

Figure 9. $\mathrm{K}_{2} \mathrm{O}$ vs. $\mathrm{SiO}_{2}$ plots for individual pumice layers from Leg 126.1 = Sample $126-790 \mathrm{~B}-2 \mathrm{H}-2,10-20 \mathrm{~cm} ; 2=$ Sample 126-790B-7H-2, 34-38 $\mathrm{cm} ; 3$ = Sample 126-790B-10H-1, 70-140 cm; 4 = Sample 126-790C-5H-1, 73-77 cm; $5=$ Sample 126-790C-8H-6, 116-120 cm; $6=$ Sample 126-791A-3H-3, 20-100 cm; 7 = Sample 126-791A-10H- 5, 53-96 cm; 8 = Sample 126-791A-22H-2, 45-50 cm; 9 = Sample 126-791A-28X-1, 66-70 $\mathrm{cm} ; 10=$ Sample 126-788C-1H-1, 34-36 cm; $11=$ Sample 126-788C-14H-4, 70-72 cm; $12=$ Sample 126-788C-22H-1, 47-49 cm; $13=$ Sample 125-785A-1H-3, 14-17 cm; 14 = Sample 125-785A-1H-5, 11-14 cm; 15 = Sample 125-785A-2H-5, 10-12 cm; 16 = Sample 126-793A-1H-3, 50-52 $\mathrm{cm} ; 17$ = Sample 126-793A-2H-5, 42-44 cm; 18 = Sample 126-793A-3H-5, 70-52 cm; and 19 = Sample 126-793A-5H-7, 40-42 cm. 

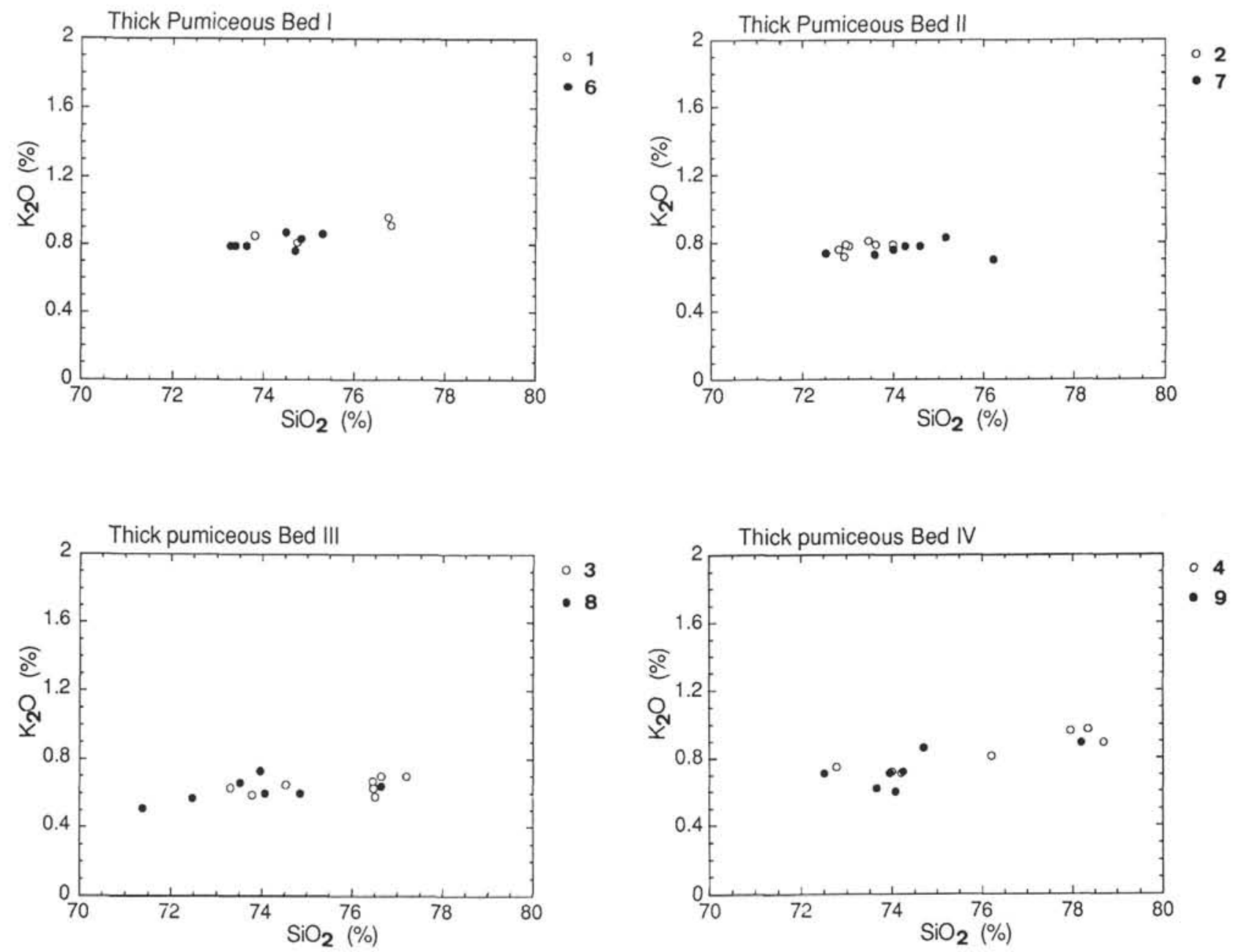

Figure 10. $\mathrm{K}_{2} \mathrm{O}$ vs. $\mathrm{SiO}_{2}$ plots for the individual thick pumiceous beds of the Sumisu Rift. Open circles are samples from Site 790; closed circles are samples from Site 791. 1 = Sample 126-790B-2H-2, 10-20 cm; 2 = Sample 126-790B-7H-2, 34-38 cm; 3 = Sample 126-790B-10H-1, 70-140 cm; $4=$ Sample 126-790C-5H-1, 73-77 cm; 6 = Sample 126-791A-3H-3, 20-100 cm; 7 = Sample 126-791A-10H-5, 53-96 cm; 8 = Sample 126-791A-22H-2, $45-50 \mathrm{~cm}$; and $9=$ Sample $126-791 \mathrm{~A}-28 \mathrm{X}-1,66-70 \mathrm{~cm}$. 


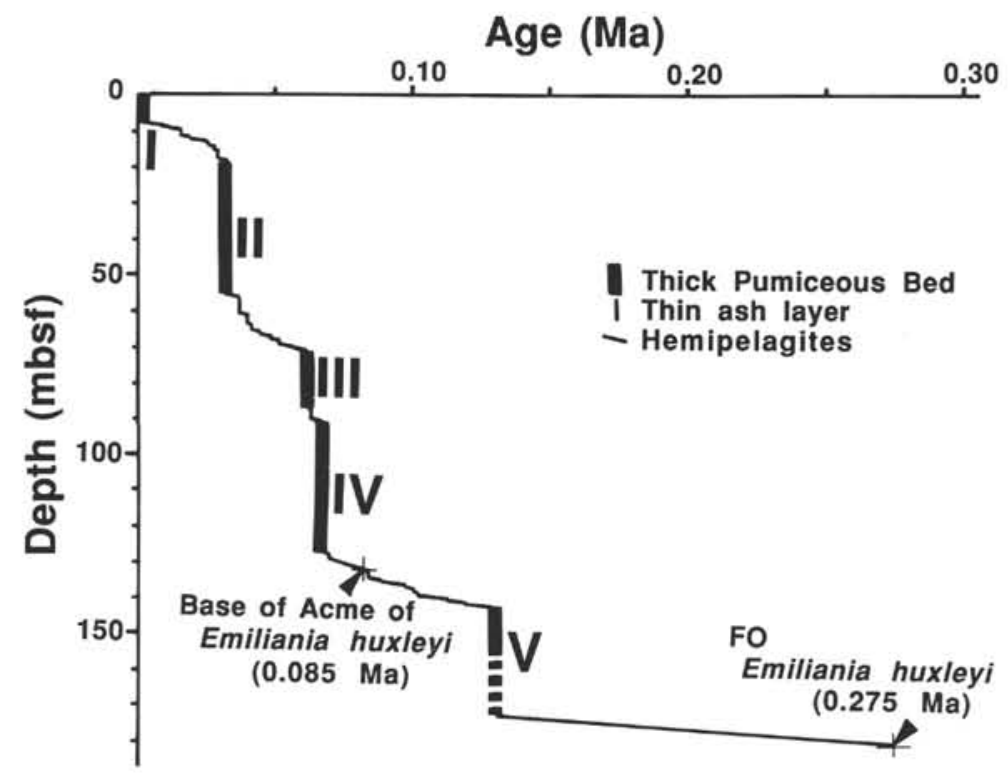

Figure 11. Plot of age vs. depth at Site 790. The data are based on shipboard core descriptions and list of ash layers (Taylor, Fujioka, et al., 1990, pp. 127-220), assuming that the hemipelagite was deposited at a constant rate between the time control points and that the ash layers were deposited instantaneously.

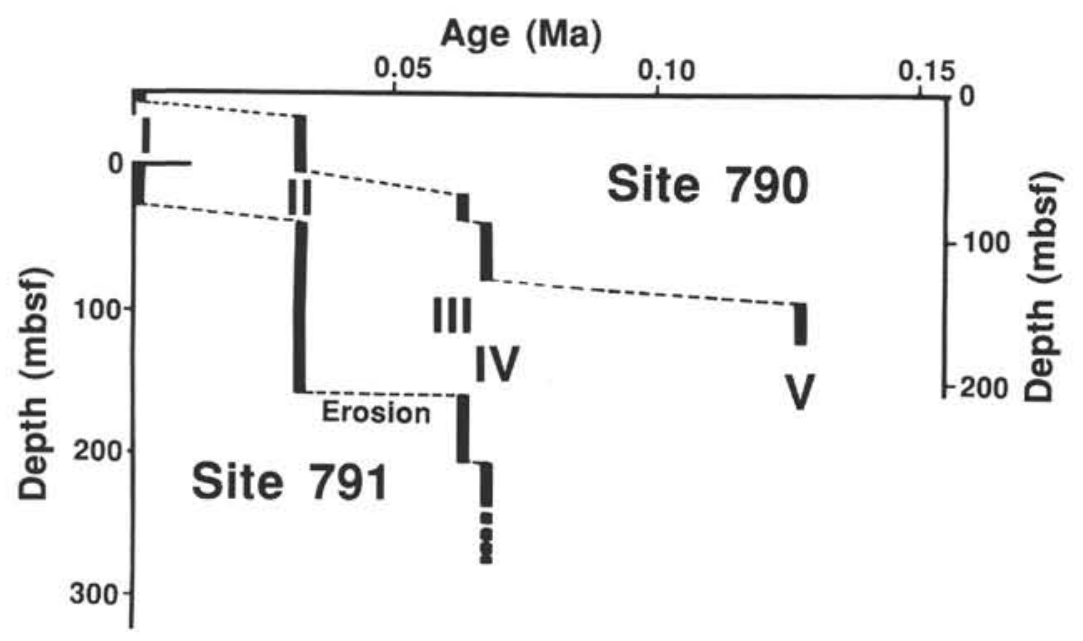

Figure 12. Correlation of thick pumiceous beds between Sites 790 and 791. Age data are based on Site 790 (Fig. 11). 


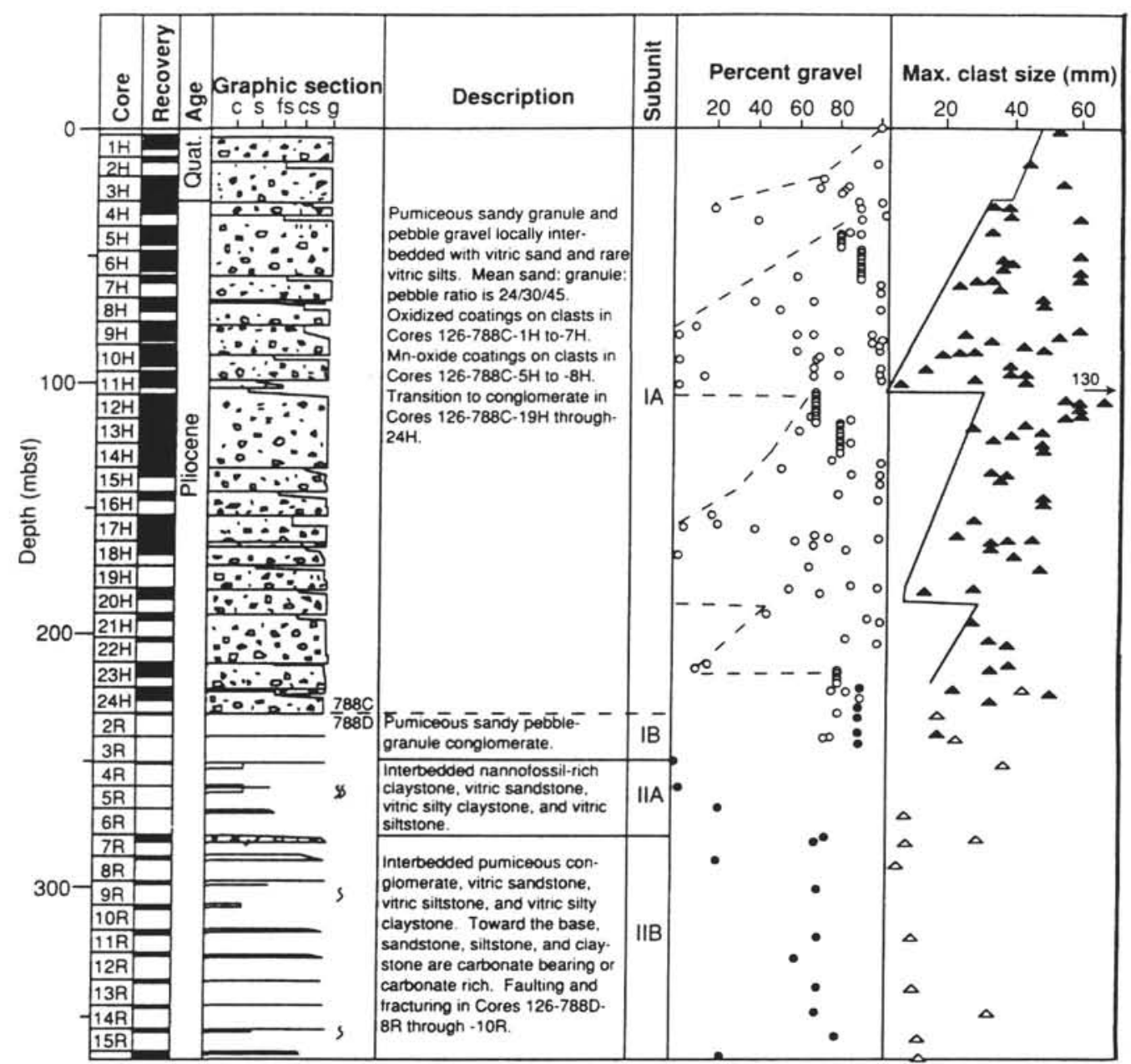

Figure 13. Lithostratigraphic units at Site 788 (Taylor, Fujioka, et al., 1990, pp. 97-126). 


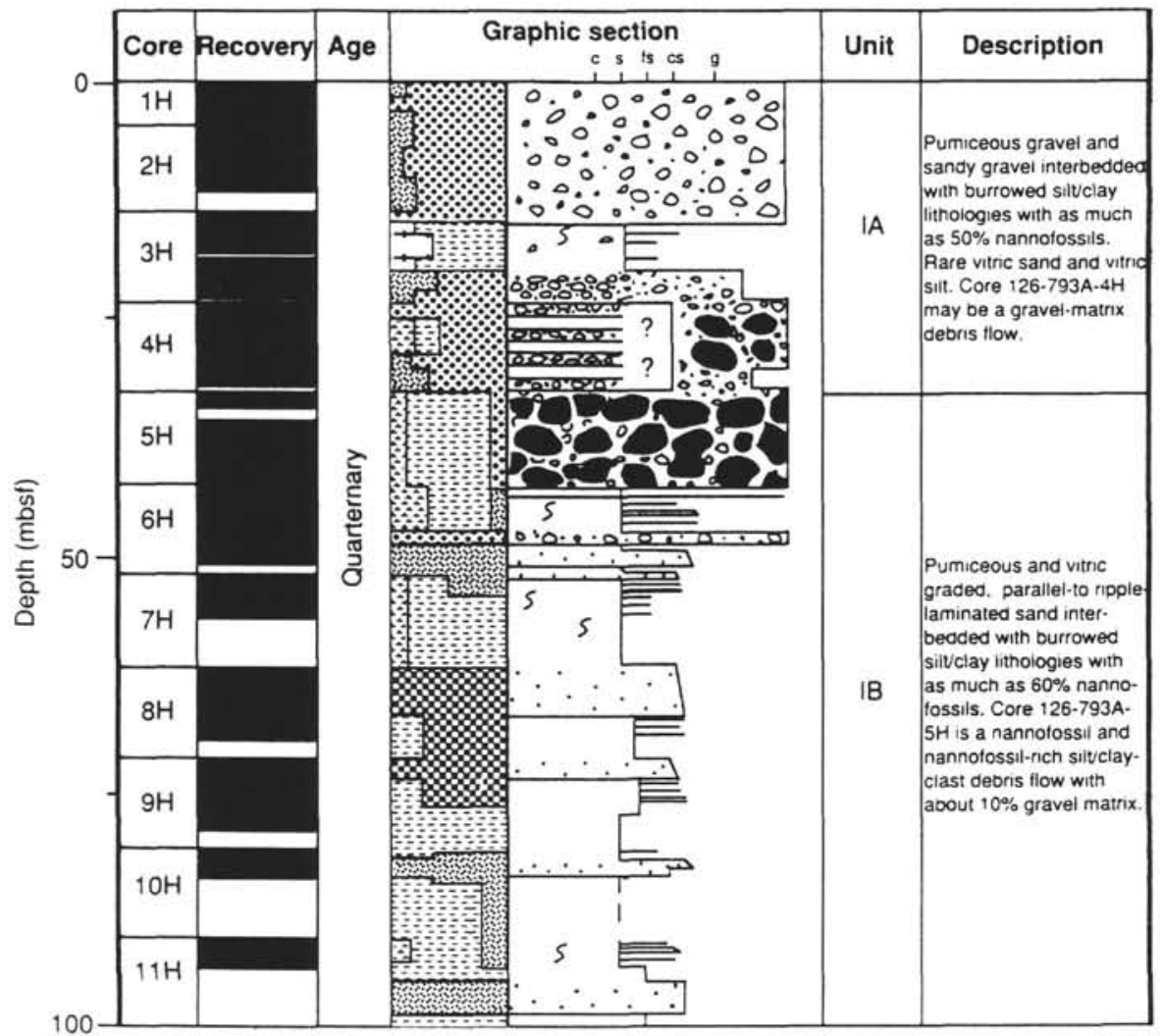

Figure 14. Lithostratigraphic units at Site 793 (Taylor, Fujioka, et al., 1990, pp. 315-403). 
$\mathrm{cm}$

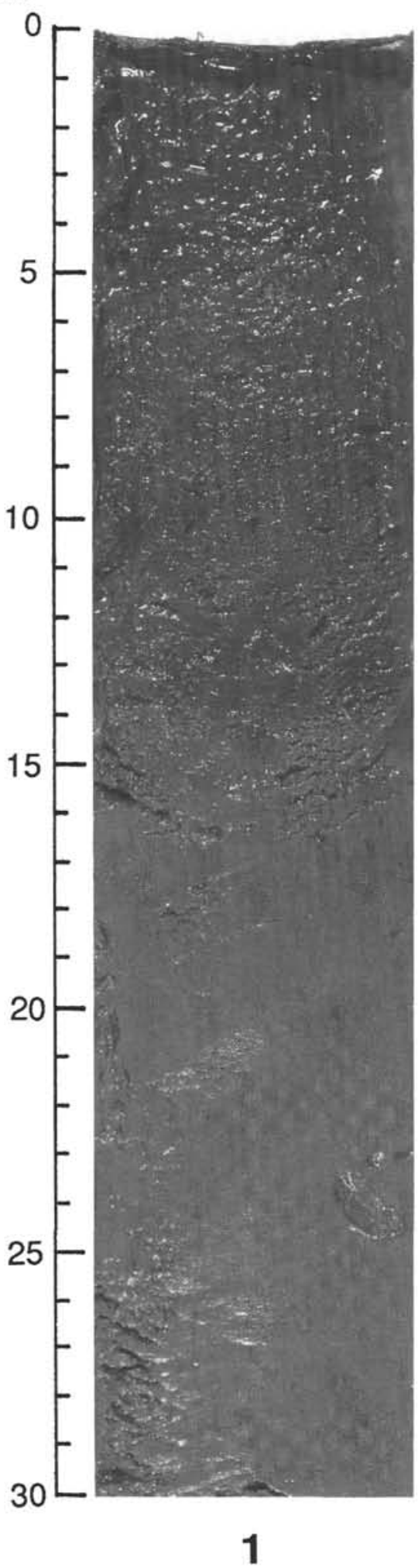

cm
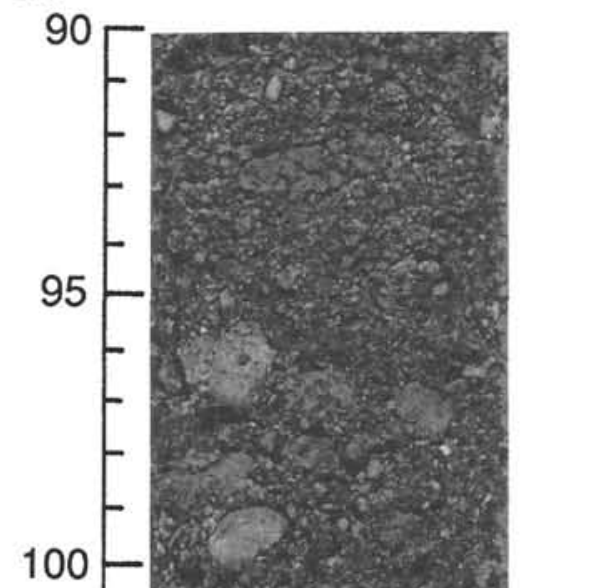

10
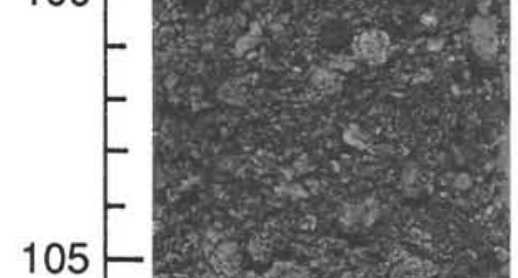

105

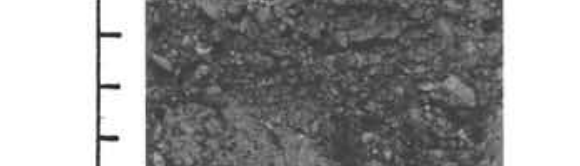

125

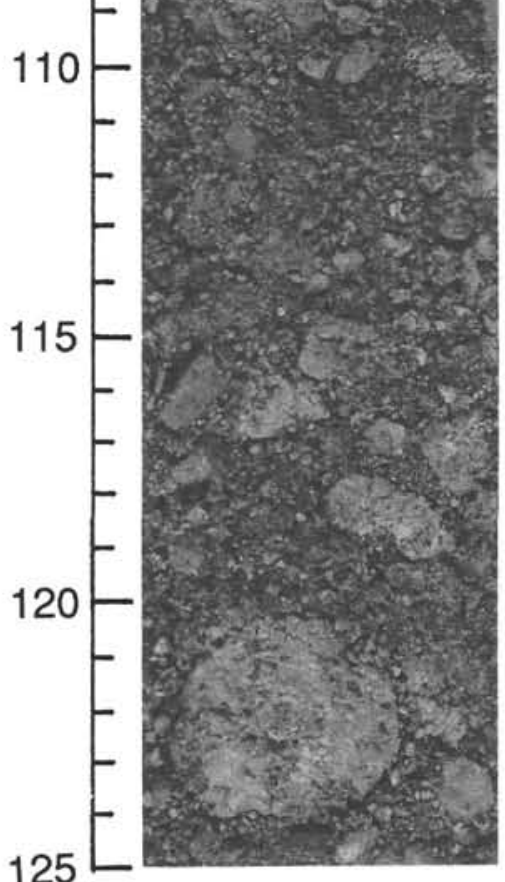

2

$\mathrm{cm}$

15

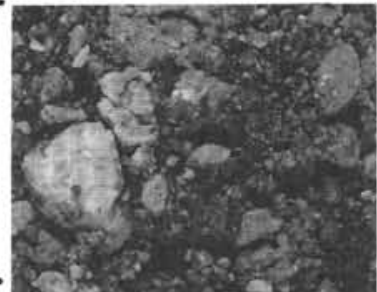

20
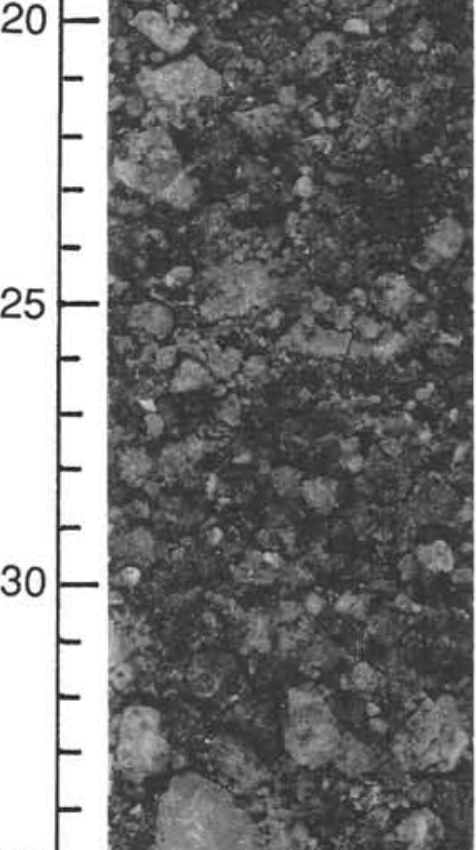

3

Plate 1. Close-up photos of pumice deposits of Leg 126. 1. Finer grained, upper portion of Thick Pumiceous Bed I at Site 790 (interval 126-790A-1H-1, 0-30 cm). The upper $13 \mathrm{~cm}$ is dark brown (10YR3/3), hemipelagic mud (mudline layer); the lower portion of the core is dark gray (5Y4/1), homogeneous, silt-size ash. 2 . Coarser portion of Thick Pumiceous Bed II at Site 790 (interval 126-790B-5H-4, 90-125 cm). The gravels are gray in color (5Y6/1); the largest pumice clast is $48 \mathrm{~mm}$ in diameter. 3. Typical interval of the coarse Pliocene deposits of flank Site 788 (interval $126-788 \mathrm{C}-4 \mathrm{H}-3,15-50 \mathrm{~cm}$ ). The dominant color of the pumice is grayish black (N2). Rare basaltic and felsic clasts also occur. 

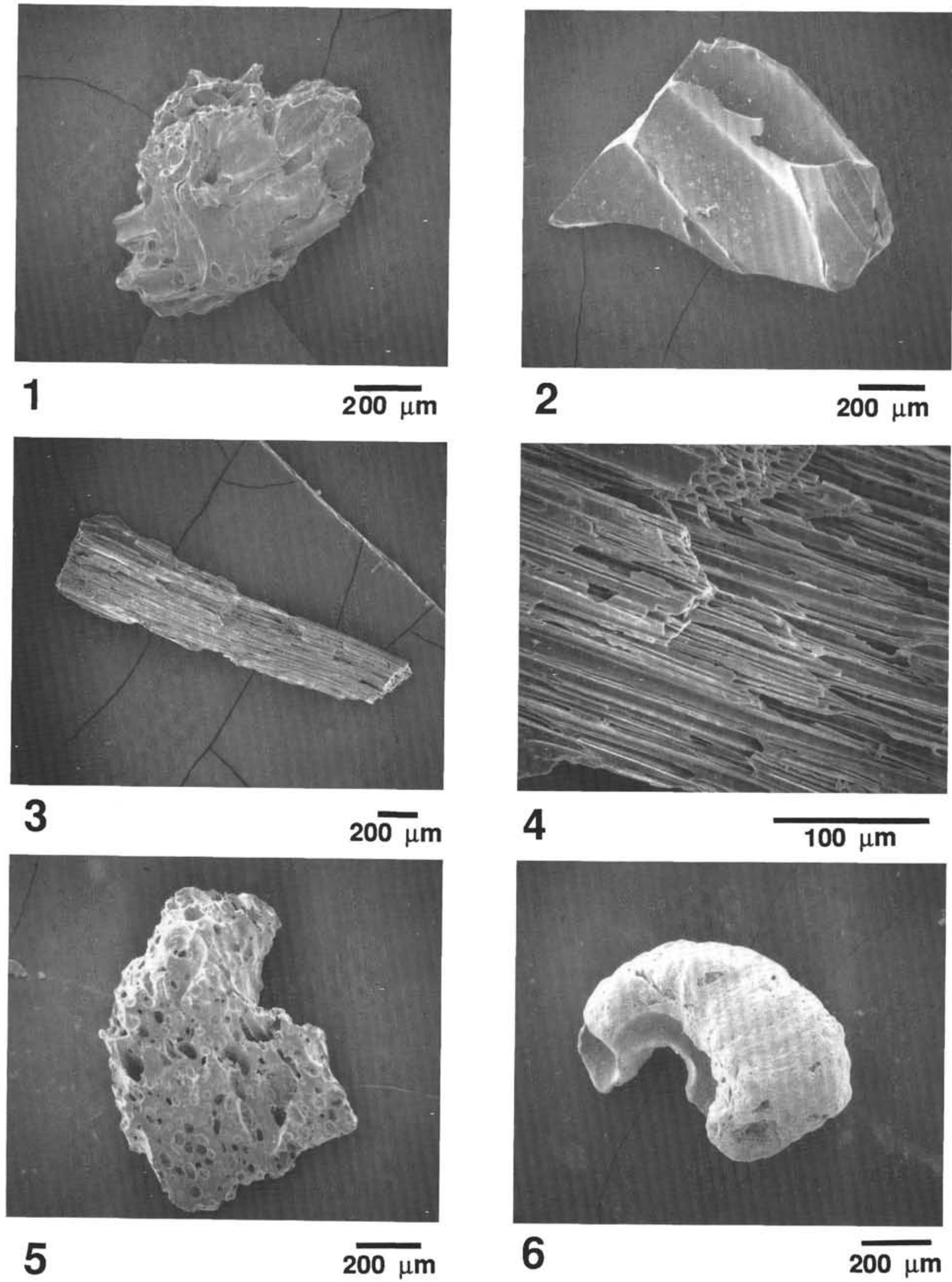

Plate 2. Scanning electron micrographs of sand-size grains from Thick Pumiceous Bed IV (Sample 126-790C-5H-3, 7-11 cm). 1. Transparent pumice-type glass. 2. Transparent bubble-wall type glass. 3. White-colored, pumice-type glass with highly elongated vesicles. 4. Enlarged view of the same sample as in Figure 3. 5. Brown-colored blocky type glass. 6. Fragment of molluscan shell. 
APPENDIX

Chemical Composition of Pumice.

\begin{tabular}{|c|c|c|c|c|c|c|c|c|c|c|c|c|c|c|}
\hline $\begin{array}{c}\text { Core. } \\
\text { Inte }\end{array}$ & $\begin{array}{l}\text { Secti } \\
\text { terval (c }\end{array}$ & & & $\begin{array}{l}\mathrm{SiO2} \\
(\%)\end{array}$ & $\begin{array}{l}\mathrm{TiO} 2 \\
(\%)\end{array}$ & $\begin{array}{c}\mathrm{Al} 2 \mathrm{O}_{3} \\
(\%)\end{array}$ & $\begin{array}{c}\mathrm{Fe}_{\mathrm{e} 2 \mathrm{O} 3} \\
(\%)\end{array}$ & $\begin{array}{l}\mathrm{MnO} \\
\left(\%_{0}\right)\end{array}$ & $\begin{array}{l}\mathrm{MgO} \\
(\%)\end{array}$ & $\begin{array}{l}\mathrm{CaO} \\
(\%)\end{array}$ & $\begin{array}{c}\mathrm{Na} 2 \mathrm{O} \\
(\%)\end{array}$ & $\begin{array}{l}\mathrm{K} 2 \mathrm{O} \\
(\%)\end{array}$ & $\begin{array}{c}\text { Akali } \\
(\%)\end{array}$ & Comment \\
\hline \multicolumn{15}{|c|}{$126-790 \mathrm{~B}$} \\
\hline $2 \mathrm{H}$. & -2 & 10. & 20 & 74.74 & 0.58 & 13.23 & 3.98 & 0,17 & 0.79 & 3.21 & 2.43 & 0.81 & 3.24 & \multirow[t]{5}{*}{ Thick Pumiceous Bed I } \\
\hline $2 \mathrm{H} \cdot$ & . 2, & 10. & 20 & 80.13 & 0.24 & 11.61 & 2.36 & 0.16 & 0.28 & 1.83 & 2.05 & 1.33 & 3.38 & \\
\hline $2 \mathrm{H}$. & -2 & 10 . & 20 & 73.79 & 0.58 & 12.93 & 4.25 & 0.17 & 1.11 & 3.57 & 2.75 & 0.85 & 3.60 & \\
\hline $2 \mathrm{H}$. & . 2 , & 10 - & 20 & 76.74 & 0.37 & 12.74 & 3.19 & 0.17 & 0.53 & 3.01 & 2.29 & 0.96 & 3.25 & \\
\hline $2 \mathrm{H}$. & - 2, & 10 . & 20 & 76.81 & 0.35 & 13.68 & 3.04 & 0.18 & 0.48 & 2.73 & 1.82 & 0.91 & 2.72 & \\
\hline \multicolumn{15}{|c|}{$126-790 \mathrm{~B}$} \\
\hline $7 \mathrm{H}$ & 2 & 34. & 38 & 73.61 & 0.57 & 14.03 & 4.05 & 0.16 & $1 . \infty$ & 3.86 & 1.90 & 0.79 & 2.68 & \multirow[t]{5}{*}{ Thick Pumiceous Bed II } \\
\hline $7 \mathrm{H}$. & - 2 . & 34. & 38 & 73.02 & 0.54 & 13.93 & 4.30 & 0.16 & 1.02 & 3.93 & 2.32 & 0.78 & 3.10 & \\
\hline $7 \mathrm{H}$. & .2 & 34. & 38 & 72.79 & 0.57 & 13.97 & 4.11 & 0.13 & 0.94 & 4.21 & 2.52 & 0.76 & 3.28 & \\
\hline $7 \mathrm{H}$. & - 2 , & 34. & 38 & 72.91 & 0.58 & 14.08 & 4.00 & 0.15 & 0.91 & 4.28 & 2.37 & 0.72 & 3.09 & \\
\hline $7 \mathrm{H}$. & .2 & 34. & 38 & 73.99 & 0.49 & 14.47 & 3.25 & 0.15 & 0.70 & 3.81 & 2.29 & 0.79 & 3.08 & \\
\hline \multicolumn{15}{|c|}{$126-790 \mathrm{~B}$} \\
\hline $10 \mathrm{H}$ & -1 & 70 . & 140 & 76.47 & 0.44 & 13.47 & 298 & 0.18 & 0.58 & 3.14 & 209 & 0.63 & 2.73 & \multirow[t]{6}{*}{ Thick Pumiceous Bed III } \\
\hline $10 \mathrm{H} \cdot$ & -1 & 70 . & 140 & 76.45 & 0.47 & 13.04 & 2.91 & 0.22 & 0.67 & 3.24 & 2.32 & 0.67 & 2.99 & \\
\hline $10 \mathrm{H}$. & -1 & 70 . & 140 & 76.64 & 0.58 & 12.75 & 3.09 & 0.14 & 0.75 & 3.01 & 2.32 & 0.70 & 3.02 & \\
\hline $10 \mathrm{H}$. & -1 & 70. & 140 & 74.53 & 0.51 & 14.20 & 3.22 & 0.16 & 0.77 & 3.56 & 2.35 & 0.65 & 3.00 & \\
\hline $10 \mathrm{H}$. & -1 & 70 . & 140 & 73.31 & 0.65 & 14.24 & 3.92 & 0.19 & 0.97 & 3.98 & 2.04 & 0.63 & 2.67 & \\
\hline $10 \mathrm{H}$ & -1 & 70 . & 140 & 73.79 & 0.59 & 13.39 & 4.10 & 0.16 & 1.12 & 3.91 & 2.35 & 0.59 & 2.94 & \\
\hline \multicolumn{15}{|c|}{$126-790 \mathrm{C}$} \\
\hline $5 \mathrm{H}$. & $\cdot 1$ & 73 . & 77 & 72.78 & 0.49 & 14.93 & 3.53 & 0.16 & 0.72 & 4.08 & 250 & 0.75 & 3.25 & Thick Pumiceous Bed IV \\
\hline $5 \mathrm{H}$. & -1 & 73 . & 772 & 74.00 & 0.51 & 14.20 & 3.41 & 0.16 & 0.63 & 4.13 & 2.24 & 0.72 & 2.96 & \\
\hline $5 H$. & -1 & 73 . & 77 & 77.96 & 0.50 & 12.36 & 2.99 & 0.11 & 0.40 & 2.77 & 1.95 & 0.96 & 2.91 & \\
\hline $5 \mathrm{H}$. & -1 & 73 . & 77 & 76.21 & 0.42 & 12.99 & 3.29 & 0.13 & 0.69 & 3.36 & 209 & 0.81 & 2.91 & \\
\hline $5 \mathrm{H}$ & - 1. & 73 . & 77 & 78.70 & 0.36 & 12.17 & 2.84 & 0.15 & 0.44 & 2.57 & 1.88 & 0.89 & 2.77 & \\
\hline $126-790 \mathrm{C}$ & & & & & & & & & & & & & & \\
\hline $8 \mathrm{H}$. & -6, & 116 - & 120 & 74.71 & 0.50 & 13.37 & 4.41 & 0.15 & 0.78 & 3.21 & 201 & 0.84 & 2.85 & Thick Pumiceous Bed V \\
\hline $8 \mathrm{H}$ - & $-6,1$ & $116-$ & 120 & 75.16 & 0.48 & 12.48 & 4.49 & 0.17 & 0.79 & 3.28 & 225 & 0.89 & 3.14 & \\
\hline $8 \mathrm{H}$. & - 6.1 & 116 . & 120 & 73.94 & 0.55 & 12.57 & 5.20 & 0.20 & 1.07 & 3.37 & 2.27 & 0.83 & 3.10 & \\
\hline $8 \mathrm{H}$. & .6. & 116 . & 120 & 77.57 & 0.47 & 11.80 & 3.63 & 0.12 & 0.52 & 2.77 & 210 & 1.02 & 3.11 & \\
\hline $8 \mathrm{H}$. & $-6,1$ & 116 . & 120 & 76.83 & 0.43 & 12.51 & 3.79 & 0.10 & 0.52 & 2.89 & 1.99 & 0.95 & 2.94 & \\
\hline $8 \mathrm{H}$ - & $-6,1$ & 116 - & 120 & 72.06 & 0.50 & 14.18 & 4.86 & 0.16 & 1.03 & 4.16 & 234 & 0.70 & 3.04 & \\
\hline $126-791 \mathrm{~A}$ & & & & & & & & & & & & & & \\
\hline $3 \mathrm{H}$. & -3 & 20 . & 100 & 74.69 & 0.60 & 13.79 & 3.82 & 0.17 & 0.70 & 3.42 & 2.02 & 0.76 & 2.78 & Thick Pumiceous Bed I \\
\hline $3 \mathrm{H}$. & 3 & 20 . & 100 & 74.48 & 0.56 & 12.53 & 4.89 & 0.18 & 0.85 & 3.53 & 2.12 & 0.87 & 2.99 & \\
\hline $3 \mathrm{H}$ - & 3 & 20 . & 100 & 73.27 & 0.61 & 13.79 & 4.37 & 0.18 & 0.86 & 3.84 & 2.30 & 0.79 & 3.08 & \\
\hline $3 \mathrm{H}$. & -3 & 20 . & 100 & 73.37 & 0.62 & 13.14 & 4.47 & 0.17 & 1.18 & 3.56 & 269 & 0.79 & 3.48 & \\
\hline $3 \mathrm{H}$ - & 3 & 20 . & 100 & 73.62 & 0.60 & 12.50 & 5.00 & 0.22 & 1.56 & 3.33 & 2.39 & 0.79 & 3.17 & \\
\hline $126-791 \mathrm{~A}$ & & & & & & & & & & & & & & \\
\hline $10 \mathrm{H}$ - & -5 & 53 . & 96 & 76.21 & 0.55 & 13.57 & 3.11 & 0.19 & 0.74 & 3.09 & 1.81 & 0.70 & 2.51 & Thick Pumiceous Bed II \\
\hline $10 \mathrm{H} \cdot$ & - 5 & 53 . & 96 & 72.51 & 0.62 & 13.98 & 4.47 & 0.19 & 1.11 & 4.22 & 2.16 & 0.74 & 2.90 & \\
\hline $10 \mathrm{H} \cdot$ & 5 & 53 . & 96 & 74.59 & 0.58 & 13.84 & 3.41 & 0.16 & 0.82 & 3.65 & 2.17 & 0.78 & 2.95 & \\
\hline $10 \mathrm{H}-$ & -5 & 53 . & 96 & 75.15 & 0.54 & 12.72 & 3.93 & 0.17 & 0.88 & 3.19 & 2.59 & 0.83 & 3.41 & \\
\hline $10 \mathrm{H}$ - & 5 & 53. & 96 & 73.59 & 0.47 & 14.52 & 3.24 & 0.14 & 0.69 & 4.28 & 2.34 & 0.73 & 3.07 & \\
\hline $126-791 \mathrm{~A}$ & & & & & & & & & & & & & & \\
\hline $22 \mathrm{H} \cdot$ & -2 . & 45 . & 50 & 72.47 & 0.75 & 14.09 & 4.42 & 0.23 & 1.38 & 4.17 & 1.88 & 0.57 & 2.45 & Thick Pumiceous Bed III \\
\hline $22 \mathrm{H}$. & $\cdot 2$ & 45 . & 50 & 74.07 & 0.65 & 13.43 & 4.33 & 0.24 & 0.92 & 3.50 & 2.26 & 0.60 & 2.86 & \\
\hline $22 \mathrm{H} \cdot$ & .2 & 45 . & 50 & 74.85 & 0.59 & 13.09 & 3.90 & 0.20 & 1.05 & 3.45 & 2.28 & 0.60 & 2.87 & \\
\hline $22 \mathrm{H}$. & 2 & 45 . & 50 & 71.38 & 0.70 & 13.68 & 4.85 & 0.24 & 1.40 & 4.39 & 2.86 & 0.51 & 3.38 & \\
\hline $22 \mathrm{H}$. & 2 & 45. & 50 & 76.64 & 0.60 & 12.61 & 3.34 & 0.20 & 0.74 & 3.25 & 1.99 & 0.64 & 2.62 & \\
\hline $126-791 \mathrm{~A}$ & & & & & & & & & & & & & & \\
\hline $28 \times$ & 1 & 66 . & 70 & 72.51 & 0.52 & 14.55 & 3.93 & 0.19 & 0.90 & 4.33 & 2.36 & 0.71 & 3.07 & Thick Pumiceous Bed IV \\
\hline $28 \times$. & 1 & 66 . & 70 & 78.20 & 0.43 & 12.39 & 2.79 & 0.18 & 0.55 & 2.67 & 1.90 & 0.89 & 2.80 & \\
\hline $28 \times$. & 1 & 66 . & 70 & 74.71 & 0.64 & 13.54 & 4.07 & 0.15 & 0.81 & 3.31 & 1.87 & 0.86 & 2.72 & \\
\hline $28 \times$. & $\cdot 1$ & 66 - & 70 & 73.96 & 0.50 & 13.86 & 3.58 & 0.15 & 0.82 & 3.78 & 2.65 & 0.71 & 3.36 & \\
\hline $28 x$. & 1 & 66 . & 70 & 74.25 & 0.48 & 13.86 & 3.37 & 0.18 & 0.76 & 3.73 & 2.66 & 0.72 & 3.37 & \\
\hline $126-788 \mathrm{C}$ & & & & & & & & & & & & & & \\
\hline $1 \mathrm{H} \cdot$ & -1 & 34. & 36 & 77.55 & 0.51 & 12.92 & 2.96 & 0.18 & 0.61 & 2.72 & 1.53 & 0.97 & 2.50 & Quaternary pumice deposits \\
\hline $1 \mathrm{H}$. & 1 & 34 - & 36 & 78.38 & 0.36 & 12.41 & 2.43 & 0.13 & 0.49 & 1.89 & 203 & 1.88 & 3.91 & \\
\hline $1 \mathrm{H}$. & 1 & 34. & 36 & 78.81 & 0.46 & 11.88 & 2.76 & 0.12 & 0.58 & 2.38 & 202 & 1.01 & 3.03 & \\
\hline $1 \mathrm{H}$ - & 1 & 34. & 36 & 77.69 & 0.48 & 12.63 & 2.80 & 0.13 & 0.71 & 2.61 & 2.08 & 0.87 & 2.95 & \\
\hline $1 \mathrm{H}$. & -1 & 34. & 36 & 68.40 & 0.44 & 11.78 & 6.68 & 0.33 & 5.50 & 4.02 & 2.29 & 0.57 & 2.86 & \\
\hline $126-788 \mathrm{C}$ & & & & & & & & & & & & & & \\
\hline $14 \mathrm{H}$ - & -4 & 70 . & 72 & 73.36 & 0.70 & 13.57 & 4.58 & 0.22 & 1.38 & 3.57 & 1.81 & 0.76 & 2.57 & Pliocene purrice deposits \\
\hline $14 \mathrm{H}$ - & -4 & 70 . & 72 & 77.48 & 0.63 & 11.72 & 3.59 & 0.15 & 0.85 & 2.66 & 1.92 & 1.01 & 2.92 & \\
\hline $14 \mathrm{H}$. & -4 & 70 . & 72 & 76.31 & 0.68 & 11.56 & 4.31 & 0.14 & 1.16 & 2.78 & 1.88 & 1.18 & 3.06 & \\
\hline $14 \mathrm{H}$. & 4 & 70 . & 72 & 73.92 & 0.74 & 12.57 & 4.82 & 0.23 & 1.33 & 3.38 & 2.26 & 0.74 & 3.00 & \\
\hline $14 \mathrm{H}$. & 4 & 70 . & 72 & 75.01 & 0.68 & 12.72 & 4.06 & 0.19 & 1.17 & 3.29 & 2.10 & 0.78 & 2.88 & \\
\hline
\end{tabular}


Appendix (continued).

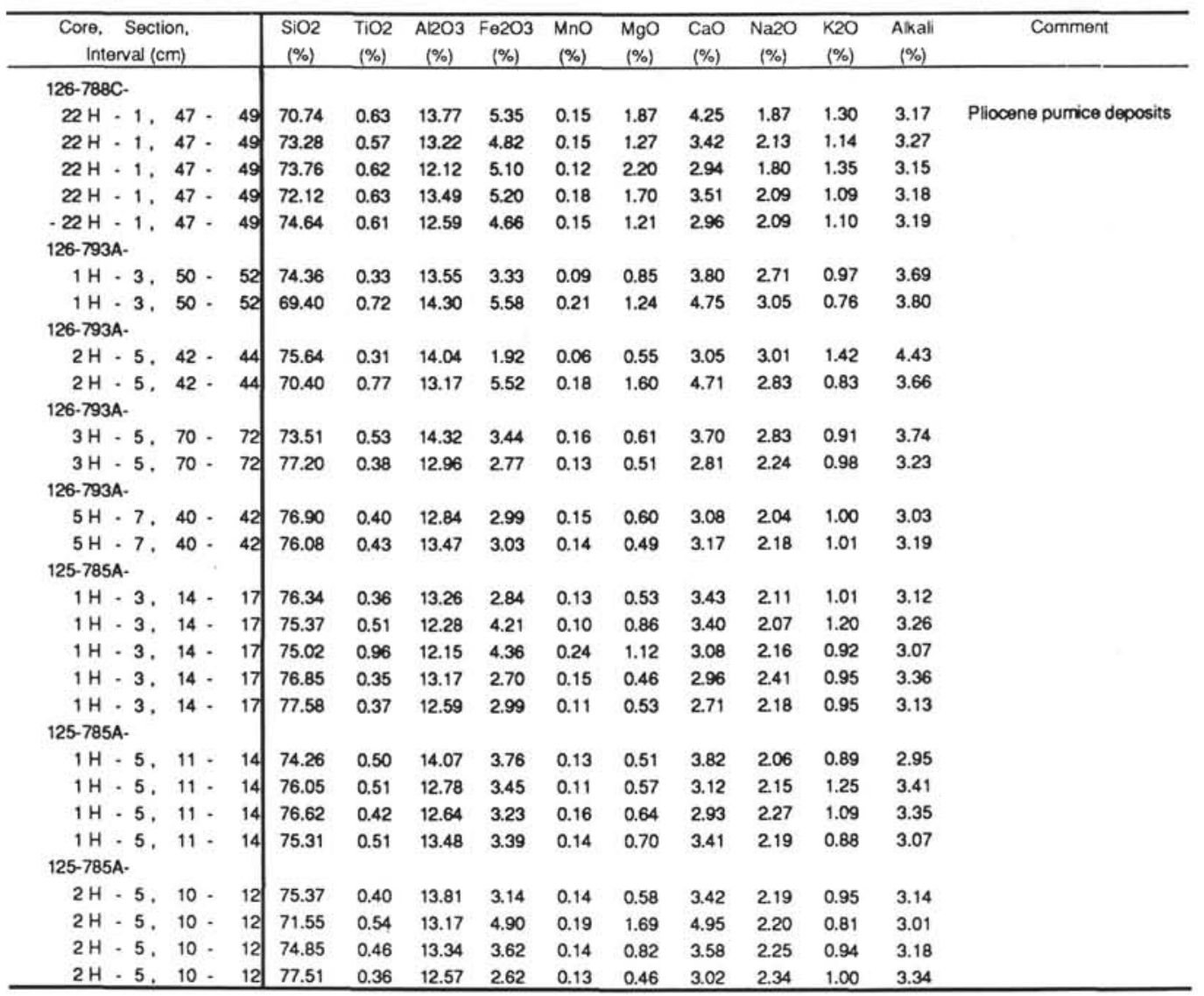

